\title{
Brachiopods from the Latham Shale Lagerstätte (Cambrian Series 2, Stage 4) and Cadiz Formation (Miaolingian, Wuliuan), California
}

\author{
Yue Liang, ${ }^{1,2} \odot$ Lars E. Holmer, ${ }^{1,2} \odot$ Xiaolin Duan, ${ }^{1}$ and Zhifei Zhang ${ }^{1 *} \odot$ \\ ${ }^{1}$ State Key Laboratory of Continental Dynamics, Shaanxi Key Laboratory of Early Life and Environments, Department of Geology, \\ Northwest University, Xi'an, 710069, China <yueliang_nwu@ outlook.com><duan_nwu@163.com><elizf@nwu.edu.cn> \\ ${ }^{2}$ Department of Earth Sciences, Palaeobiology, Uppsala University, SE-752 36, Uppsala, Sweden <lars.holmer@ pal.uu.se>
}

\begin{abstract}
A moderately diverse assemblage of brachiopods from the Latham Shale Lagerstätte (Cambrian Series 2, upper Stage 4) and the upper Cadiz Formation (Miaolingian, Wuliuan), California is described in detail for the first time. The fauna includes both linguliform and rhynchonelliform brachiopods-Hadrotreta primaea (Walcott, 1902), Paterina prospectensis (Walcott, 1884), Dictyonina pannula (White, 1874), and Mickwitzia occidens Walcott, 1908; and Nisusia fulleri Mount, 1981 and Wimanella highlandensis (Walcott, 1886), respectively-together with olenellid trilobites and hyolithids. The fauna differs from other Cambrian Konservat-Lagerstätten (notably Cambrian Series 2 Chengjiang and Guanshan Lagerstätten, eastern Yunnan) in that the brachiopod shell valves in many cases are still preserved with their original mineralization. Moreover, the excellently preserved shale-hosted valves even include cases with exquisite epithelial cell molds, otherwise only seen in acid-etched material from carbonate rocks. The pitted ornamentation in D. pannula closely resembles that described from Ordovician linguliforms. The unusual preservation of $N$. fulleri provides important clues for ancestral composition of the brachiopod shell. The two articulated rhynchonelliform species probably represent the oldest records of this group from the west Laurentia. The fauna could also represent the earliest onset of the transition from the Cambrian Evolutionary Fauna (CEF) to the Paleozoic Evolutionary Fauna (PEF).
\end{abstract}

\section{Introduction}

Lower Cambrian rocks are widely distributed in the Great Basin of western United States. Besides the extensive research on trilobite assemblages from this region (e.g., Palmer, 1964; Sundberg and McCollum, 2003), brachiopods-one of the most abundant faunal components of benthic communities in this area-have been the subject of several studies for more than a century. It was the extensive, pioneering fieldwork mainly by Walcott $(1902,1905,1908)$ and Rowell (1966, 1977, 1980; Rowell and Henderson, 1978) that made the Great Basin one of the best-studied regions of Laurentia concerning brachiopods. The lower Cambrian biostratigraphy in White-Inyo Mountains/ Esmeralda County has been well studied (Fig. 1); abundant archaeocyathids and trilobites, together with brachiopods and hyoliths, are known from the Campito and the Poleta Formation (e.g., Nelson, 1978; Rowland et al., 2008; Hollingsworth, 2011; Cordie et al., 2019); small skeletal brachiopods and associated fossils were reported from the Harkless Formation (Skovsted and Holmer, 2006). In contrast, less is known from the comparable Marble Mountains area.

The lower Cambrian Latham Shale crops out prominently in two ranges, the Providence Mountains and the Marble Mountains, in the Eastern Mojave of Southern California

*Corresponding author.
(Fig. 1.1, 1.2). Although the formation is highly fossiliferous, descriptions of this fauna are quite rare. The only available brief report of the entire fauna was published by Mount (1980), who unfortunately provided only sketchy line drawings of the taxa. The Latham Shale is well known for its abundant and well-preserved olenellid trilobites, but most importantly, also yields exceptionally preserved fossils (Liang et al., 2020a). The fauna includes 12 trilobites and three brachiopods, as well as mollusks, annelids, anthozoans, echinoderms, algae, and one ichnofossil (Mount, 1980). Some of them have been well reported, e.g., the stem group arthropod Anomalocaris Whiteaves, 1892 (Briggs and Mount, 1982), the alga Margaretia Walcott, 1931 (Waggoner and Hagadorn, 2004), some unnamed early Cambrian palaeoscolecidans (Conway Morris and Peel, 2010), eocrinoids (Durham, 1978), and enigmatic conical fossils (Waggoner and Hagadorn, 2005). However, a detailed description of the brachiopod assemblage has never been published.

The highest lower Cambrian unit is the Cadiz Formation of Hazzard and Mason (1936). The Cadiz Formation contains both early and middle Cambrian fossils, but the stage level boundary has not been determined (Mason, 1935). The fauna is less fossiliferous and less studied when compared to the underlying Latham Shale with 13 trilobites, three brachiopods, two mollusks, and one siliceous sponge (Mason, 1935). Among them, three brachiopods and five trilobites have been described with sketched illustrations by Mount (1980). 
1
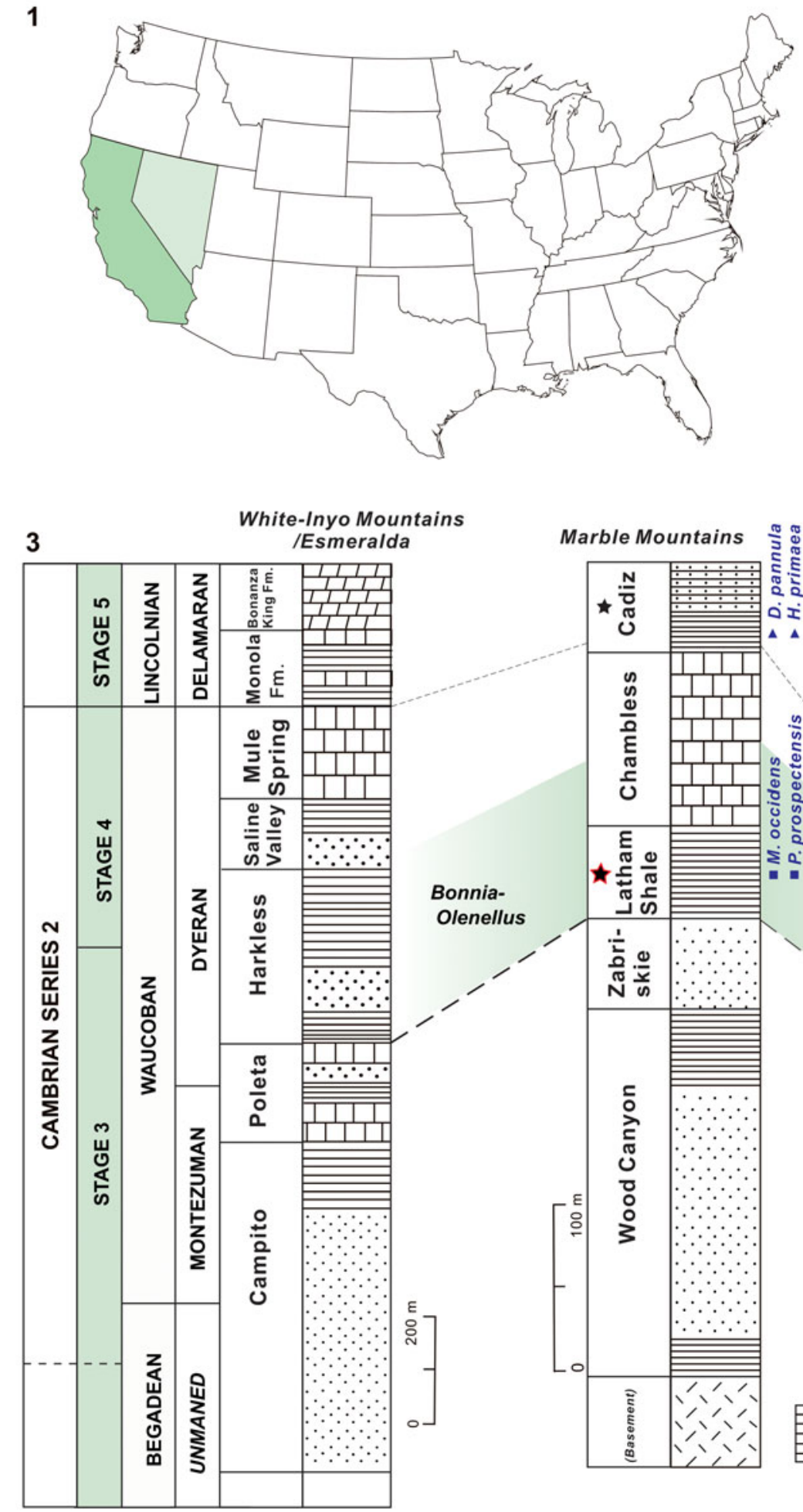

3

White-Inyo Mountains
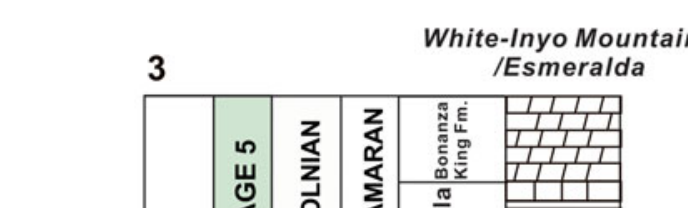

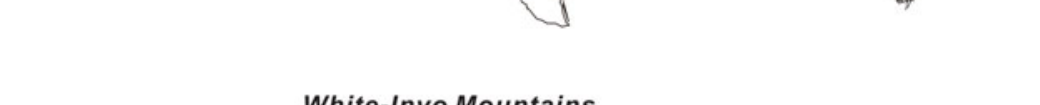


The main objective of this paper is to provide the first comprehensive description of the brachiopods from the Latham Shale Lagerstätte (unnamed Series 2, upper Stage 4) and the upper Cadiz Formation (Miaolingian, Wuliuan) in the Providence Mountains and the Marble Mountains area, California. The fauna treated here includes four linguliform and two rhynchonelliform species and could represent the earliest onset of the transition from the Cambrian Evolutionary Fauna (CEF) to the Paleozoic Evolutionary Fauna (PEF).

\section{Geological setting}

The Latham Shale is best known from exposures in the southern Providence Mountains and the Marble Mountains (Fig. 1.1, 1.2), where fossils have been collected for over a century (e.g., Darton, 1907; Clark, 1921; Mount, 1980). According to Hazzard (1954), the Latham Shale is $\sim 15-45 \mathrm{~m}$ thick, with gray-green shale, platy micaceous siltstone, sandstone, and a minor amount of limestone. The shale weathers to red, paper-thin fragments and contains abundant olenellid trilobites, indicating that the formation lies within the Bonnia-Olenellus Biozone (Mount, 1980).

The Cadiz Formation (Hazzard and Mason, 1936) was redefined by Hazzard (1954) by lowering the lower boundary to include a $33+\mathrm{m}$ interval of the lower Cambrian strata. The formation consists of a heterogeneous assemblage of lithologies including sandstone, shale, siltstone, and limestone. The early Cambrian part of the Cadiz Formation lies in the Olenellus multinodus Subzone of the Bonnia-Olenellus Zone; the middle Cambrian portion of the Cadiz Formation contains faunas from the middle Cambrian Plagiura-Poliella, Albertella, and Glossopleura biozones, however, they have not received critical biostratigraphical study (Mount, 1980; Waggoner and Collins, 1995).

The specimens from the Latham Shale Lagerstätte and the Cadiz Formation originate from the collections of the University of California, Riverside (UCR). Unfortunately, historic museum collections from this area often lack precise locality and stratigraphic information. Some of the fossils have localities recorded only as 'Marble Mountains' or 'southern end of the Marble Mountains.' This probably indicates the best-known trilobite collecting areas in the Marble Mountains, which are near a limestone quarry at the southern tip of the mountain range, $\sim 4 \mathrm{~km}$ (2.5 mi) north and east of the settlement of Cadiz, south of the National Trails Highway (formerly U.S. Route 66) (Waggoner and Hagadorn, 2005).

\section{Material and methods}

Fossils were examined under a Zeiss Stemi 305 microscope and photographed with a Zeiss Smart Zoom 5 Stereo-micrographic system and Cannon camera 5D Mark IV mounted on a photographic system. Uncoated specimens were examined with a FEI Quanta 400-FEG scanning electron microscope (SEM), equipped with backscattered and secondary electron detectors in addition to an energy-dispersive X-ray analyser (EDX) operating at accelerating voltages ranging from $5-15 \mathrm{kV}$, at the Department of Geology, Northwest University (NWU), Xi' an, China. Some specimens were tested by Bruker M4 Tornado table-top energy-dispersive micro-X-ray fluorescence ( $\mu$-XRF) to characterize the elemental abundances in samples from the fluorescence spectrum. Specimens were covered by wax for better preservation of the shell surface, so they were photographed and coated with ammonium chloride $\left(\mathrm{NH}_{4} \mathrm{Cl}\right)$ to reduce reflecting light during photography. Some of the shells have been subjected to deep weathering, and they were usually preserved as internal molds. To better display the ornamentation and shell structures in detail, a number of latex casts or molds were prepared using polyvinyl butyral (PVB) ethanol solution and latex.

Other materials examined.-In addition to the fossils from the Latham Shale Lagerstätte and the Cadiz Formation, six specimens of Hadrotreta primaea (Walcott, 1902) from the basal Emigrant Formation of Split Mountain, Nevada, and one specimen of Heliomedusa orienta Sun and Hou, 1987 from the Chengjiang Lagerstätte, South China were collected for comparison.

Repositories and institutional abbreviations.-Most of the fossil specimens examined in this study were loaned from University of California, Riverside (UCR), USA. Other cited repositories are ELI=Early Life Institute, Northwest University Xi' an, China; and USNM = National Museum of Natural History (United States National Museum), Smithsonian Institution, Washington, DC, USA.

\section{Systematic paleontology}

Phylum Brachiopoda Duméril, 1806

Subphylum Linguliformea Williams et al., 1996

Class Lingulata Gorjansky and Popov, 1985

Order Acrotretida Kuhn, 1949

Superfamily Acrotretoidea Schuchert, 1893

Family Acrotretidae Schuchert, 1893

Genus Hadrotreta Rowell, 1966

Type species.-Acrotreta primaea Walcott, 1902, from the lower to middle Cambrian Pioche Shale, Nevada, USA.

Hadrotreta primaea (Walcott, 1902)

Figure 2

1902 Acrotreta primaea Walcott, p. 593.

1912 Acrotreta primaea; Walcott, p. 700, pl. 69, figs. la-f.

1966 Hadrotreta primaea; Rowell, p. 13, pl. 1, figs. 1-12.

1980 Hadrotreta primaea; Rowell, p. 7, pl. 4, figs. 8-12, pl. 5, figs. 1-10, pl. 6, figs. 1-9.

1990 Hadrotreta primaea; Roberts and Jell, figs. 22-24, table 3.

2007 Hadrotreta primaea; Holmer and Popov, p. 113, fig. 57.1a-f.

Hypotype.-A dorsal valve (UCR 7312/1), Cadiz Formation, California, USA (Fig. 2.1, 2.2).

Description.—Dorsal valve subcircular in outline, of $6.89 \mathrm{~mm}$ width, $5.82 \mathrm{~mm}$ length (Fig. 2.1, 2.2). Shell gently convex, 


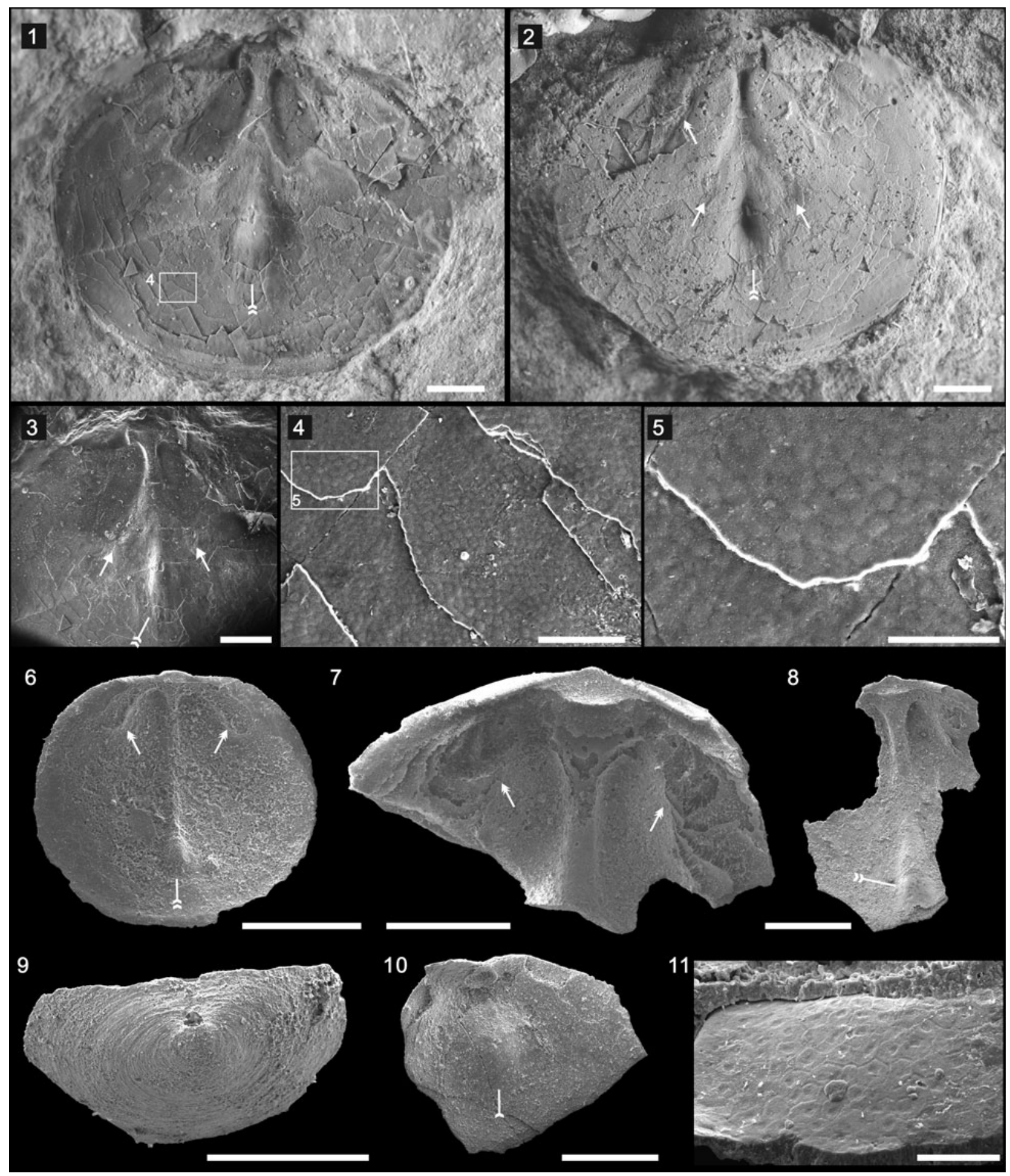

Figure 2. Hadrotreta primaea (Walcott, 1902): (1-5) from the Cadiz Formation (UCR 7312/1); dorsal valve (1, with boxed area of [4]) and latex cast (2) showing the median buttress, swelling median septum terminal (double-tailed arrows), cardinal muscle scars (double-headed arrow), and elongate impressions of anterocentral muscle scars on the lateral edge of the median septum (arrows); (3-5) SEM images showing swelling median septum terminal (double-tailed arrow), elongate impressions of anterocentral muscle scars (arrows), and the epithelial molds; (6-11) from the basal Emigrant Formation, Split Mountain, Nevada: (6) dorsal interior (ELI SMS 5) showing the median buttress, swelling median septum terminal (double-tailed arrow), and cardinal muscle scars (double-headed arrows); (7) enlarged dorsal interior (ELI SMS 3) showing well-defined cardinal muscle scars (double-headed arrows) and median buttress; (8) internal surface of a dorsal valve (ELI SMS 1) showing median septum and swelling median septum terminal (double-tailed arrow); (9) posterior view of the ventral valve (ELI SMS 8); (10) internal view of a ventral valve (ELI SMS 9) showing the apical process (single-tailed arrow); (11) the epithelial cell molds preserved in the interior surface of a ventral valve (ELI SMS 10). Scale bars $=1 \mathrm{~mm}(\mathbf{1 - 3}) ; 500 \mu \mathrm{m}(\mathbf{6}-\mathbf{1 0}) ; 100 \mu \mathrm{m}(\mathbf{4}) ; 50 \mu \mathrm{m}(\mathbf{5}, \mathbf{1 1})$ 
most strongly convex posteromedially, becoming gradually flattened anteriorly, with maximum width at midlength (Fig. 2.1, 2.2). Dorsal pseudointerarea small, occupying 27\% of total valve width, with faint median groove and propareas (Fig. 2.3). Dorsal median buttress strongly developed, extending $33 \%$ of valve length; strongly developed ridge-like median septum originating at approximate distal end of median buttress, extending $\sim 67 \%$ of total valve length; terminal portion of median septum forming subtriangular platform-like swelling (Fig. 2.1-2.3, double-tailed arrows). Elongate impressions of anterocentral muscle scars on lateral edge of median septum (Fig. 2.2, 2.3, arrows). Cardinal muscle scars weakly impressed, extending anterolaterally from lateral edge of median groove, occupying $20 \%$ of total length, $46 \%$ of valve width (Fig. 2.2, doubled-headed arrow). Epithelial cell molds on different shell layers, 7.22-12.57 $\mu \mathrm{m}$ in diameter (Fig. 2.4, 2.5).

Materials. - One dorsal valve (UCR 7312/1) recovered from the Cadiz Formation. Three dorsal valves (ELI SMS 1, 3, 5) and three ventral valves (ELI SMS 8, 9, 10) collected from the basal Emigrant Formation, Split Mountain, Nevada.

Remarks.-After the genus Acrotreta was erected by Kutorga in 1848, the type material of the type species Acrotreta subconica Kutorga, 1848 was lost and there was a lack of detailed information concerning interior characters, type locality, and type horizon. As a result, the genus was subsequently used worldwide as a 'waste basket' for almost any conical acrotretides from the Cambrian-Ordovician. Holmer and Popov (1994) revised the type species and related lingulate brachiopods and suggested that Acrotreta is restricted to the Ordovician, because none of the numerous Cambrian records of the genus (see, e.g., Walcott, 1912) can be retained within the taxon. Rowell (1966) erected the genus Hadrotreta as monotypic; its diagnosis and description were based on the etched topotype material of Acrotreta primaea.

Hadrotreta primaea has been described from the Pioche Shale of Nevada (Rowell, 1980) and the Coonigan Formation of western New South Wales, Australia (Roberts and Jell, 1990). The etched material of Hadrotreta primaea from the basal Emigrant Formation (Fig. 2.6-2.11) highly resembles the shale-hosted material, whereas the former has better-developed anterocentral muscle scars (Fig. 2.6, 2.7, arrows), a platform-like swelling at the termination of the dorsal median septum (Fig. 2.6, 2.8, double-tailed arrows), a ventral intertrough (Fig. 2.9) and most importantly a moderately high cape-like ventral apical process (Fig. 2.10, tailed arrow). Specimens from the lower Cambrian of South Australia referred to Hadrotreta primaea by Brock \& Cooper (1993) were later assigned to Vandalotreta djagoran (Kruse, 1990) by Holmer et al. (1996). In 2014, Percival and Kruse reassigned the material to Kostjubella Popov, Holmer, and Gorjansky, 1996. ?Hadrotreta primaea has been described from the Harkless Formation, southern Nevada (Skovsted and Holmer, 2006), although the lack of internal information for the ventral valve hampered its accurate affinity.

Hadrotreta primaea differs from Hadrotreta taconica (Walcott, 1887) from the Forteau Formation of southern
Labrador and western Newfoundland by having a morepronounced, boss-like anterior termination of dorsal median ridge, and shorter dorsal pseudointerarea (Skovsted et al., 2017). Hadrotreta primaea is similar to Hadrotreta timchristiorum Popov et al., 2015 from the Himalaya (Popov et al., 2015), although the latter has a narrower and shallower ventral intertrough. The epithelial cell molds are reminiscent of those in etched material in their overall impression and average diameter, but those from acid-etched carbonate material better preserve the hexagonal network (Fig. 2.11).

Class Paterinata Williams et al., 1996

Order Paterinida Rowell, 1965

Superfamily Paterinoidea Schuchert, 1893

Family Paterinidae Schuchert, 1893

Genus Paterina Beecher, 1891

Type species.-Obolus labradoricus Billings, 1861 from the lower Cambrian of Labrador, Canada.

\section{Paterina prospectensis (Walcott, 1884)}

Figures 3, 8.1

1884 Kutorgina prospectensis Walcott, p. 19, pl. 9, fig. 1, 1a, b. 1886 Kutorgina prospectensis; Walcott, p. 106, pl. 9, fig. 3, 3a. 1897 Iphidea prospectensis; Walcott, p. 234.

1905 Iphidella prospectensis; Walcott, p. 307.

1912 Micromitra (Paterina) prospectensis; Walcott, p. 352, pl. 2, fig. 4, 4a.

1980 Paterina prospectensis; Mount, fig. 2.

2020a Paterina prospectensis; Liang et al., fig. 1a, b, e, f.

Hypotype.-A dorsal valve (UCR 10/2006), lower Cambrian Latham Shale, California, USA (Fig. 3.3).

Description.-Shell ventribiconvex, subcircular in outline (Fig. 3.1-3.12). Shells relatively large, of $4.89-8.87 \mathrm{~mm}$ length, $5.99-11.2 \mathrm{~mm}$ width, with maximum width at midlength. Ventral valve convex, with apex at posterior part (Fig. 3.1-3.8). Ventral posterior margins oblique, well-illustrated in examined specimens (Fig. 3.1-3.8). Pseudointerarea and homeodeltidium poorly preserved. Dorsal valve less convex, with well-defined, nearly straight hinge line (Fig. 3.9-3.12). Dorsal valve larger than ventral valves in current collection. Shell interior not observed. External ornamentation on both valves consisting of regular, fine, concentric fila. Concentric growth lines spaced regularly (10-12 per mm; Fig. 3.13, 3.14), sometimes interrupted by nick points, forming sets of drapes (Fig. 3.4, 3.15).

Materials.-Four dorsal (UCR 7002/300, 10/3366, 7271/6, and 4079/10/1) and eight ventral valves (UCR 10/3381, 10/3354, 10/2006, 7002/298, 10/3362, 10/3351, 10/8/34, and 10/3369), including one complete conjoined shell (UCR 10/3369) and one dorsal valve with soft-part preservation (UCR 7002/300; Liang et al., 2020a), recovered from the lower Cambrian Latham Shale.

Remarks.-Paterina prospectensis was originally assigned to Kutorgina Billings, 1861 and Iphidea Billings, 1872 by 


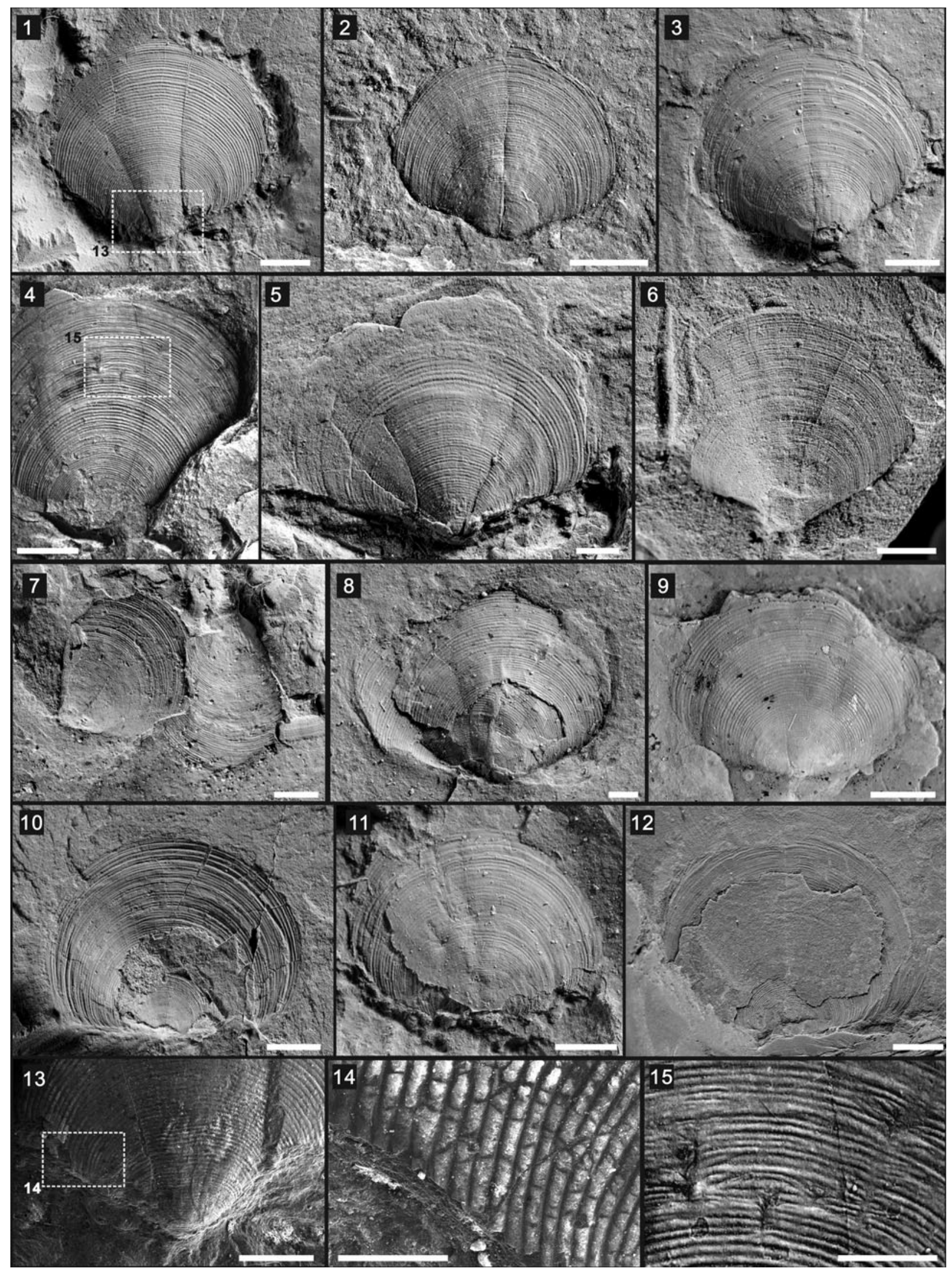

Figure 3. Paterina prospectensis (Walcott, 1884): (1) ventral valve exterior (UCR 10/3381), with boxed area of (13); (2) ventral valve exterior (UCR 10/3354); (3) ventral valve exterior (UCR 10/2006); (4) ventral valve exterior (UCR 7002/298) with boxed area of (15); (5) ventral valve exterior (UCR 10/3362); (6) ventral valve exterior (UCR 10/3351); (7) ventral valve exterior (UCR 10/8/34); (8) ventral valve exterior and dorsal valve interior (UCR 10/3369); (9) dorsal valve exterior (UCR 4079/10/1); (10) dorsal valve exterior (UCR 7271/6); (11) dorsal valve exterior (UCR 10/3366); (12) dorsal valve exterior (UCR 7002/300); (13, 14) SEM images showing the prominent growth lines (UCR 10/3381) and boxed area of (14); (15) enlarged view of boxed area in (4), showing drapes and nick points on the surface. Scale bars = $2 \mathrm{~mm}(\mathbf{1 - 1 2}) ; 1 \mathrm{~mm}(\mathbf{1 3}, \mathbf{1 5}) ; 500 \mu \mathrm{m}(\mathbf{1 4})$. 
Walcott, but he later transferred it to Micromitra Meek, 1873, based on its concentrically striated ornamentation. Later, it was known as Paterina prospectensis (see Mount, 1976, 1980; Gaines and Droser, 2002). The specimens studied here show distinct ornamentation of concentric growth fila and are markedly different from the surface ornamentation of Micromitra (Williams et al., 1998). Another prominent difference between Paterina and Micromitra is that the former has an open delthyrium whereas the latter has a homeodeltidium (Laurie, 2000). Both genera belong within the class Paterinata, in which Paterina has a slightly earlier first appearance datum (FAD) and became extinct in the late Ordovician (Williams et al., 1998).

The most comparable well-known species is Paterina zenobia Walcott, 1924, which is only known from the Burgess Shale (e.g., Topper et al., 2015). Both $P$. prospectensis and $P$. zenobia share a similar subcircular outline with a straight hinge line, although $P$. zenobia generally attains a larger size, reaching a maximum of $15 \mathrm{~mm}$ width and $14 \mathrm{~mm}$ length (Topper et al., 2015). The two species are also similar in the way they preserve the long marginal setae fringing the shell valve. Topper et al. (2015) suggested that the sessile life strategy of $P$. zenobia might have included mimicry; the occurrence of P. prospectensis might suggest that this had already developed by Stage 4 (Liang et al., 2020a). The poorly preserved open delthyrium and internal structures of the flattened material of $P$. prospectensis preclude further comparison. Other occurrences in the early Cambrian of Laurentia are difficult to compare in detail to $P$. prospectensis. Paterina sp. indet. from the Forteau Formation of southern Labrador and western Newfoundland, Canada has been kept under open nomenclature without formal description (Skovsted et al., 2017). The ventral valves of P. mediocris Poulsen, 1932 from the Ella Island Formation, northeastern Greenland, share a similar overall morphology and general concentric fila with $P$. prospectensis, but the ventral valve of the latter is more convex and has a more oblique posterior margin (Skovsted and Holmer, 2005).

Paterina? suspiciosa Aksarina, 1975 from the Parahio Formation, Tethyan Himalaya, shows concentric ornament typical for Paterina, but also retains a homeodeltidium, which is otherwise absent in other species of the genus characterized by an open delthyrium. Paterina sp. indet. from the same formation is more subrectangular in outline, but the lack of a ventral valve impedes further comparison (Popov et al., 2015). Paterina has also been reported from England, USA, France, and Spain (Termier and Termier, 1974; Laurie, 1987, 2000; Liñán and Mergl, 1982), however, the lack of internal musculature and vascular systems for the material of $P$. prospectensis prohibits further detailed comparison.

\section{Genus Dictyonina Cooper, 1942}

Type species.-Trematis pannulus White, 1874 from the lower to middle Cambrian Pioche Shale, Nevada, USA.

Dictyonina pannula (White, 1874)

Figure 4.1-4.7

1874 Trematis pannulus White, p. 6.
1912 Micromitra (Iphidella) pannula; Walcott, p. 361.

1942 Dictyonina pannula; Cooper, p. 228.

1976 Dictyonina pannula; Mount, fig. 28.

Holotype.-A dorsal valve (USNM 15331a), lower to middle Cambrian Pioche Shale, Nevada, USA (Rowell, 1980).

Description.-Shell semicircular to rounded rectangular, unequally biconvex, slightly flattened or compressed, but somewhat profiled laterally (Fig. 4.1-4.4). Ventral valve ovate to subquadrate, small, of $1.2 \mathrm{~mm}$ length, $1.9 \mathrm{~mm}$ width (Fig. 4.1, 4.2). Umbo bearing a prominent metamorphic shell, $\sim 600 \mu \mathrm{m}$ in diameter (Fig. 4.1, 4.2). Dorsal valve gently convex at umbo, flattened laterally and anteriorly, with nearly straight posterior margin (Fig. 4.3, 4.4). Dorsal valve relatively large, of $5.56 \mathrm{~mm}$ length, $7.75 \mathrm{~mm}$ width (Fig. 4.3, 4.4). Ornament of fine radiating rows of subhexagonal pits arising near umbo, increasing in size moderately by intercalation anteriorly; 8-10 concentric growth bands recognizable, alternatingly widening toward marginal edge (Fig. 4.3, 4.4). Diameter of pits $20-50 \mu \mathrm{m}$ (Fig. 4.5-4.7). Ventral and dorsal interior not observed.

Materials.-One ventral (UCR 7073/1) and one dorsal valve (UCR 9925/9) recovered from the Cadiz Formation.

Remarks.-Dictyonina pannula is the type species of the genus. The holotype is a poorly preserved dorsal valve (USNM 15331a) that retains a small part of the original shell typified by the characteristic pitted ornament. The precise stratigraphic level from which the holotype came is unknown. It was collected in the Pioche District and previous studies show that only one species of Dictyonina occurs in the lower and middle Cambrian rocks of that area (Rowell, 1980).

Species of the Cambrian paterinate brachiopod Dictyonina from the lower to upper Cambrian are characterized by fine radiating rows of subhexagonal pits increasing in size distally (Laurie, 2000). This pitted ornament also represents a significant character in the younger, related genus Dictyonites from the Lower-Upper Ordovician, but Dictyonites has a more deeply pitted and perforated shell and pits increasing significantly in size distally (Laurie, 2000). The oldest known mickwitziid brachiopod Kerberellus marcouensis Devaere, Holmer, and Clausen in Devaere et al., 2015 was previously described as Dictyonina? sp. indet. due to its ornamentation with radiating rows of subhexagonal pits. However, the latest revision of the problematic Kerberellus marcouensis suggested that the two species only share superficial similarities; Kerberellus marcouensis is characterized by large, radially ovoid, hourglass-shaped extensions that are interpreted as tubes (canals) running through a thick shell, the most significant character of the mickwitziid brachiopods, whereas the fine radiating rows in Dictyonina correspond to subhexagonal pits in the organophosphatic shell (Devaere et al., 2015).

Dictyonina hexagona (Bell, 1941) from the middle Cambrian of Montana, has hexagonal external pits, but these are much finer and the ventral valve has a more prominent umbo extending well behind the hinge line of the valves. Specimens 

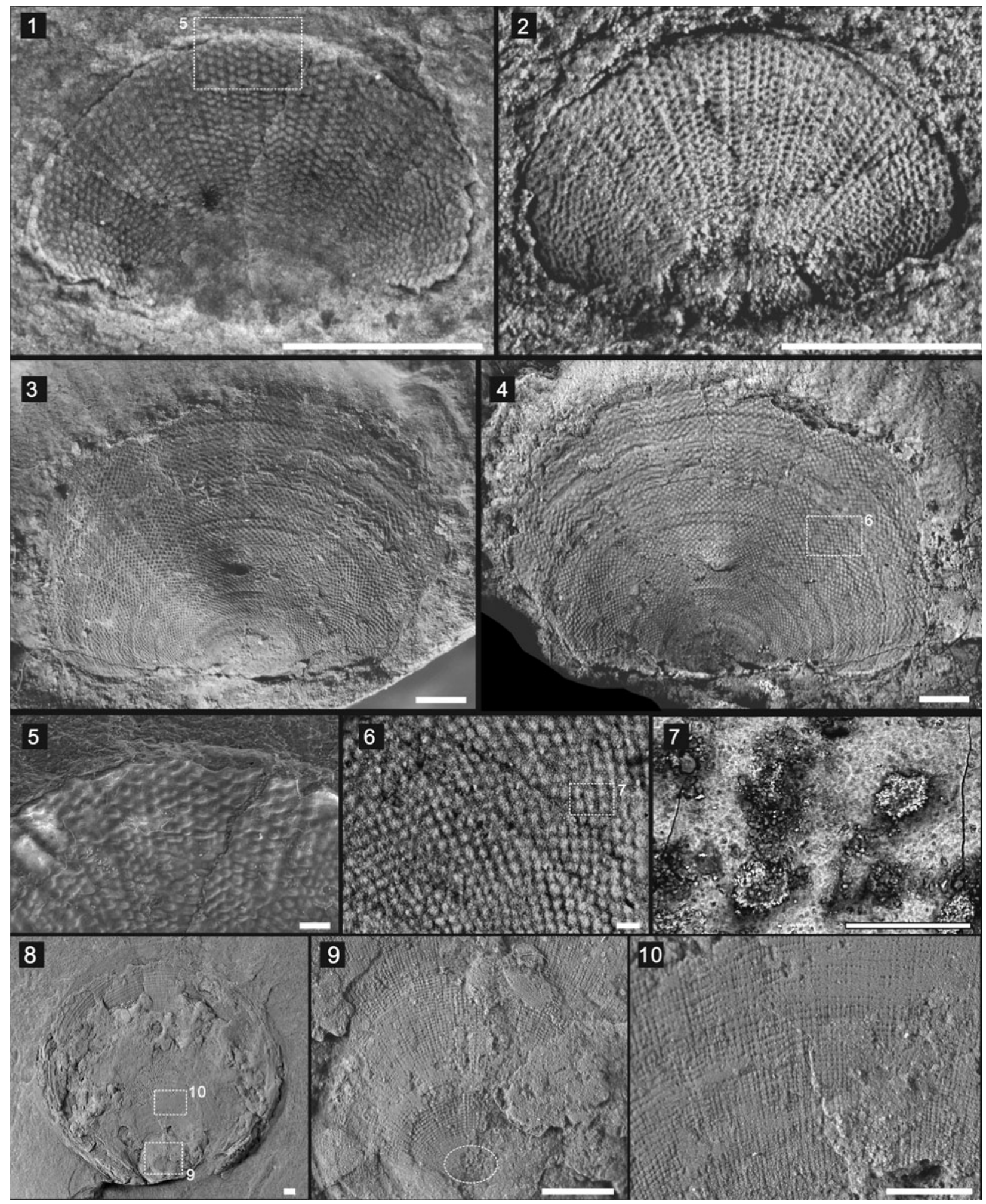

Figure 4. Dictyonina pannula (White, 1874) and Mickwitzia occidens Walcott, 1908: (1-7) D. pannula: $(\mathbf{1}, \mathbf{2})$ ventral valve (1) with boxed area of (5), and its latex cast (2) (UCR 7073/1); (3,4) dorsal valve (3) and its latex cast (4) with boxed area of (6) (UCR 9925/9); (5) enlarged view of boxed area in (1) showing the pitted ornament; (6) enlarged view of boxed area in (4) showing the pitted ornament and concentric growth lines, with boxed area of (7); (7) SEM image of boxed area in (6) showing the pitted ornament; (8-10) Mickwitzia occidens (UCR 10/8/1): (8) dorsal valve with boxed areas of (9 and 10); (9) enlarged view of boxed area in (8) showing reticulate-pustulose ornamentation and smooth metamorphic shell indicated by dashed oval; (10) enlarged view of boxed area in (8) showing the reticulatepustulose ornamentation. Scale bars $=1 \mathrm{~mm}(\mathbf{1 - 4 , 8 - 1 0}) ; 100 \mu \mathrm{m}(\mathbf{5 - 7})$. 
of $D$. hexagona illustrated by Koneva (1986) from the middle Cambrian of southern Kazakhstan have a less-prominent ventral umbo and coarser pitted ornament than the American material and are morphologically closer to D. pannula. Dictyonina australis Roberts and Jell, 1990 from the Coonigan Formation, western New South Wales resembles D. pannula but has a lessdefined umbo, coarser diamond-shaped pits, and prominent radial ribs (Roberts and Jell, 1990).

The pitted ornament of Dictyonina pannula is shallow and consequently is readily affected by abrasion or diagenetic effects. Wright (1981) discussed the development of pits in Dictyonina, noting an increase in breadth and a reduction of definition with age. The formation and function of the coarsely pitted ornamentation in Ordovician linguliform brachiopods has been extensively discussed by Holmer et al. (2017), however, those for Cambrian paterinides still remains poorly understood.

Stem group Brachiopoda

'Mickwitziids' sensu Holmer and Popov, 2007

(including Mickwitziidae Gorjansky, 1969)

Genus Mickwitzia Schmidt, 1888

Type species.—Lingula? monilifera Linnarsson, 1869 from the lower Cambrian (Series 2, Stage 4) Mickwitzia Sandstone Member of the File Haidar Formation near Lugnås, Västergötland (Sweden).

Mickwitzia occidens Walcott, 1908

Figures 4.8-4.10, 7.1

1908 Mickwitzia occidens Walcott, p. 54, pl. 7, fig. 1.

1912 Mickwitzia occidens; Walcott, p. 331, pl. 6, fig. 4.

1976 Mickwitzia occidens; Mount, fig. 3.

1977 Mickwitzia occidens; Rowell, p. 79, pl. 1, fig. 12.

1980 Mickwitzia occidens; Mount, fig. 3.

?1992 Mickwitzia muralensis Walcott, 1913; McMenamin, p. 181, figs. 4.1, 5.4, 5.6.

non 2002 Mickwitzia cf. Mickwitzia occidens; Holmer et al., text-figs. 2, 3.

2003 Mickwitzia occidens; Skovsted and Holmer, fig. 2.

non 2003 Mickwitzia cf. Mickwitzia occidens; Skovsted and Holmer, p. 3, figs. 3-5, 7-12.

non 2005 Mickwitzia cf. Mickwitzia occidens; Skovsted and Holmer, p. 327, pl. 1, figs. 9-13.

2007 Mickwitzia occidens; Holmer and Popov, fig. 1711d-i.

non 2007 Mickwitzia sp. cf. Mickwitzia occidens; Holmer and Popov, figs. 1712, 1713.

2010 Mickwitzia occidens; English and Babcock, fig. 4a, b.

2011 Mickwitzia occidens; Hollingsworth and Babcock, fig. 5.6, 5.7.

2015 Mickwitzia occidens; Butler et al., figs. 3-13.

2020a Mickwitzia occidens; Liang et al., fig. 1c, d, g.

Holotype.-An exfoliated valve (USNM 51518a), lower Cambrian (= Series 2), Silver Peak quadrangle, Esmeralda County, Nevada, U. S. Geological Survey locality 174c (Walcott, 1908, pl. 7, fig. 1; reillustrated by Rowell, 1977, pl.
1, fig. 12). According to Rowell (1977) and Mount (1980), the holotype was collected from the Harkless Formation in the lower part of the Bonnia-Olenellus Zone.

Description.-Outline of dorsal valve ovoid with apex at posterior margin (Fig. 4.8), more or less flat in lateral profile as other shale-hosted specimens. Size large, of $23 \mathrm{~mm}$ length, $26 \mathrm{~mm}$ width. Reticulate-pustulose ornament, typical of all known species of Mickwitzia, well defined (Fig. 4.9, 4.10). Concentric growth lines and radial costellae radiating from apex at posterior margin, with $\sim 16$ fila and 20 costellae per $\mathrm{mm}$ (Fig. 4.9, 4.10). Smooth metamorphic shell, $\sim 500 \mu \mathrm{m}$ in diameter, in posterior part of dorsal valve (Fig. 4.9).

Material.-One dorsal valve (UCR 10/8/1) recovered from the Latham Shale.

Remarks.—Mickwitzia remains an enigmatic taxon. Although it has an overall brachiopod-like appearance with two bilaterally symmetrical valves, it exhibits no character diagnostic for any know group of brachiopods, making it a hotly debated topic for nearly a century. Although Mickwitzia is neither new to paleontology nor rare in the lower Cambrian strata (e.g., Schmidt, 1888; Walcott, 1912; Rowell, 1977; McMenamin, 1986; Nemliher, 2001; Balthasar, 2004; Skovsted et al., 2009; Butler et al., 2015; Liang et al., 2020a, b), its phylogenetic position has never been satisfactorily resolved. Holmer and Popov (2007) included Mickwitzia and Heliomedusa Sun and Hou, 1987 within the informal grouping of mickwitziid-like stem-group brachiopods. The taxonomic composition and phylogenetic position of this informal grouping need to be further investigated.

Detailed research in last two decades has greatly enhanced our understanding of mickwitziids. Balthasar (2004) suggested a close relationship between Mickwitzia muralensis (Mural Formation, Canada) and paterinids due to similarities in their stratiform shell microstructure, parvicostellate ornament, and posterior margin of juvenile and early-mature shells. Skovsted et al. (2009) reported an unnamed new species of Mickwitzia from Australia; the morphology of the dorsal valve apex and the extended cones on the internal surface indicate a close affinity with Mickwitzia muralensis from the lower Cambrian of British Columbia, and extend the known range of the pivotal stem group brachiopod Mickwitzia to East Gondwana. Butler et al. (2015) described Mickwitzia occidens from the Indian Springs Lagerstätte (Cambrian Stage 3), Nevada and suggested that the inwardly pointing cones are not consistent with the setalbearing structure as previously thought. Furthermore, the presence of acrotretid-like shell structures and shell-penetrating setae in Mickwitzia occidens strengthen the previously proposed close relationship between stem-group brachiopods and tommotiids. Liang et al., (2020b) restudied Heliomedusa orienta from the Chengjiang Konservat-Lagerstätte and indicated its reticulate-pustulose ornament, tubular structure, and its marginal mantle setae and shell penetrative setae closely related to the type species Mickwitzia monilifera.

The specimen of Mickwitzia occidens collected from the Latham Shale is remarkably similar to specimens of Heliomedusa orienta from the Chengjiang Lagerstätte in size, 
morphology, preservation of setae, and the reticulate-pustulose ornament. Besides, the preservation mode also bears some overall similarities to the Chengjiang-type preservation in weathering and replication of the shell and soft parts as iron oxides. The occurrence of Heliomedusa-like Mickwitzia in the Latham Shale represents an important stratigraphic extension of this taxon in North America, making it reasonable to suggest that the FAD of mickwitziids in Laurentia and Gondwana could be diachronous (Liang et al., 2020a). Although it is possible that Mickwitzia is a senior synonym of Heliomedusa, there remain difficulties in making detailed taxonomic comparisons between shale-hosted and three-dimensional material, and more material preserved in the Latham Shale is needed to test this hypothesis.

Subphylum Rhynchonelliformea Williams et al., 1996 Class Kutorginata Williams et al., 1996 Order Kutorginida Kuhn, 1949

Superfamily Nisusioidea Walcott and Schuchert in Walcott, 1908

Family Nisusiidae Walcott and Schuchert in Walcott, 1908 Genus Nisusia Walcott, 1905

Type species.—Orthisina festinata Billings, 1861, from unnamed Cambrian Stage 4 (Bonnia-Olenellus Zone) of USA and Canada.

Nisusia fulleri Mount, 1981

Figures 5.1-5.7, 9.1

1980 Nisusia fulleri; Mount, fig. 4.

1981 Nisusia fulleri Mount, figs. 1, 2.

Holotype.-A dorsal valve (UCR 10/2031), Latham Shale of California, USA (Mount, 1981).

Description.-Shell transversely semioval in outline (Fig. 5.15.7), of 2.68-7.04 mm length, 3.82-7.59 mm width. Hinge line shorter than maximum width at midlength. Cardinal extremities slightly acute to almost rectangular; anterior commissure rectimarginate (Fig. 5.1, 5.3). Dorsal valve moderately and evenly convex, slightly carinate, with maximum convexity at posterior part; lateral slopes planar to gently concave. Umbo small, gently incurved (Fig. 5.1, 5.3). Thick costellae ornamenting shell surface, with median costellae most thickened; number of costellae increasing by intercalation and separated by narrow interspaces; hollow spines distributed in interspaces, $~ 60$ $\mu \mathrm{m}$ in diameter, separated by $300 \mu \mathrm{m}$ (Fig. 5.1-5.4), presenting on some broken shells (Fig. 5.5, 5.6). Cross striation on radial costellae, more prominent at distal $14 \%$ shell length where costellae become thicker. In total, $\sim 12$ ribs per $3 \mathrm{~mm}$ along anterior margin of mature individual. Dorsal interior not observed.

Materials.-Two slabs (UCR 10/2031 and 10/2023) of specimens, including at least five valves, recovered from the Latham Shale.

Remarks._Nisusia has most commonly been regarded as a poorly defined 'waste basket' taxon, due to the fact that the morphology of many species described in the first half of the previous century are inadequately known. However, Holmer et al., (2019) recently reviewed the phylogeny and distribution of nisusioid brachiopods and restricted Nisusia to species provided with radiating costellae bearing hollow spines. Holmer et al. (2019) also suggested that most of the taxa (mainly from Laurentia) from the lower Cambrian (unnamed stages 3-4) that have been assigned to Nisusia, belong neither to Nisusia nor to Nisusioidea, and presently only 19 taxa, plus one described under open nomenclature, can be assigned to Nisusia with some degree of confidence, whereas the generic affinities of five more species require further study.

Nisusia fulleri from the Latham Shale was excluded from the genus due to insufficient description and illustrations, and was considered to be a nomen dubium (Holmer et al., 2019). The new information on $N$. fulleri provided here substantiates the presence of thick costellae and hollow spines (Fig. 5.1-5.6), thus making it reasonable to bring the species back to the Nisusia group.

To date, four of the five nisusiid species documented from the unnamed Cambrian Series 2, including Eoconcha austini Cooper, 1951, Nisusia festinata (Billings, 1861), Nisusia ancauchensis Benedetto and Foglia, 2012, and Nisusia fulleri described herein, are from Laurentia, suggesting that this continent was probably the major center of early Cambrian nisusiid dispersal (Holmer et al., 2019). Nisusia fulleri is closely similar to the type species $N$. festinata, with the latter being spinocostellate and appears to have costellae of more even size and a narrower, deeper sulcus. Shell valves of $N$. ancauchensis, from olistolith (unnamed Cambrian Stage 4, Bonnia-Olenellus Zone), Quebrada Ancaucha, Argentina, is more convex and is ornamented with wider costellae (Benedetto and Foglia, 2012).

Class Rhynchonellata Williams et al., 1996

Order Orthida Schuchert and Cooper, 1932

Suborder Orthidina Schuchert and Cooper, 1932

Superfamily Orthoidea Woodward, 1852

Family Bohemiellidae Havlíček, 1977

Genus Wimanella Walcott, 1908

Type species.-Wimanella simplex Walcott, 1908 from the lower Cambrian of eastern British Columbia, Canada.

Wimanella highlandensis (Walcott, 1886) Figures 5.8-5.10, 9.2

1886 Orthis? highlandensis Walcott, p. 119, pl. 8, fig. 3, 3a, 3b. 1905 Billingsella highlandensis; Walcott, p. 237.

1932 Wimanella highlandensis; Schuchert and Cooper, p. 50. 1981 Nisusia fulleri; Mount, fig. 2.

Holotype.-One valve (USNM 15355c), eastern side of anticline near Pioche, Nevada (Mount, 1974a, who did not characterize it as dorsal or ventral).

Description.- Shell subrectangular to trapezoidal in outline, $\sim 16.37 \pm 2.10 \mathrm{~mm}$ in width, with length/width ratio of 0.77 $(\mathrm{N}=3)$ (Fig. 5.8-5.10). Rectangular to gently obtuse cardinal extremities; maximum width at midlength or slightly anterior to hinge line. Ventral valve moderately and evenly convex 

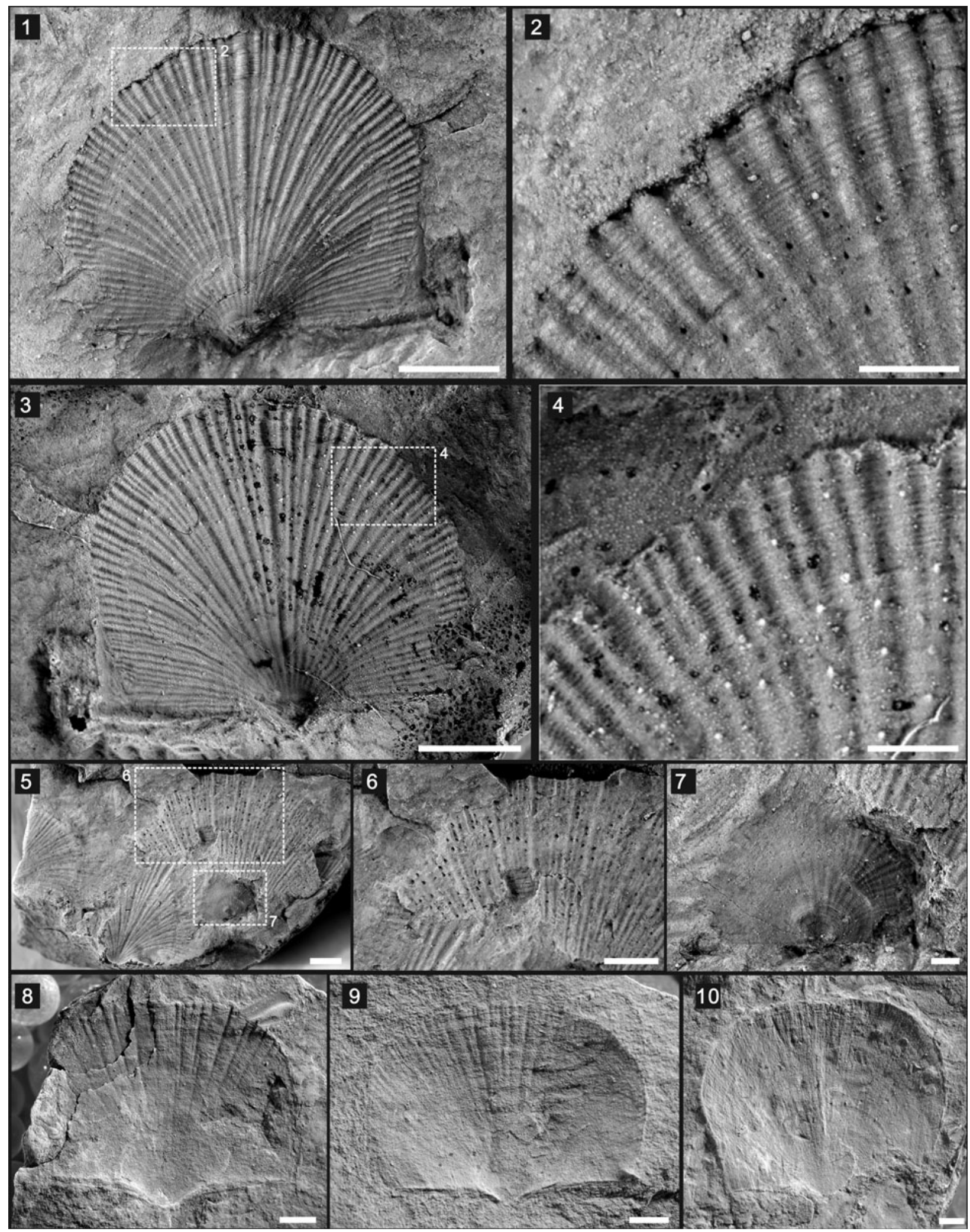

Figure 5. Nisusia fulleri Mount, 1981 and Wimanella highlandensis (Walcott, 1886): (1-4) N. fulleri (UCR 10/2031): (1) dorsal valve exterior, with boxed area of (2); (2) enlarged view of boxed area in (1) showing thick constellate ornament and hollow spines on the anterior of the shell; (3) latex cast of the specimen in (1), with boxed area of (4); (4) enlarged view of boxed area in (3) showing the thick constellate ornament; (5-7) N. fulleri (UCR 10/2023): (5) an aggregation of individuals, with boxed areas of (6 and 7); (6) enlarged view of boxed area in (5) showing thick constellate ornament and hollow spines; (7) enlarged view of boxed area in (5), showing larval individual of $N$. fulleri; (8-10) Wimanella highlandensis, ventral valves (UCR 10/2019B, 7307-13, 7307/5, respectively). Scale bars = 2 mm $(\mathbf{1 , 3}, \mathbf{5}$, 6, 8-10); $500 \mu \mathrm{m}(2,4,7)$. 

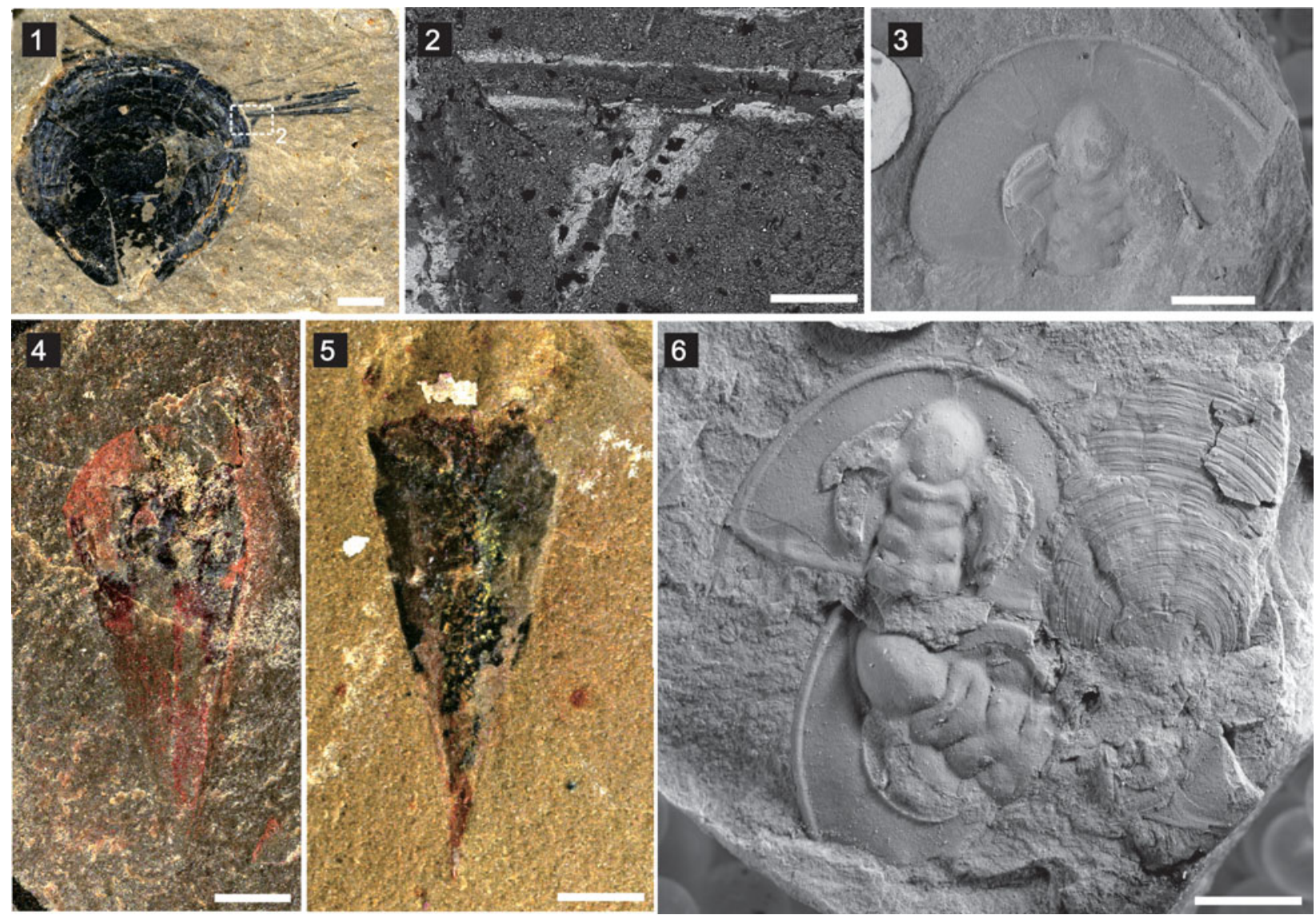

Figure 6. Other taxa from the Latham Shale: (1) brachiopod individual with possible Sphenothallus attached on the anterolateral part of the shell (UCR 7002/301), with boxed area of (2); (2) enlarged backscattered SEM image of boxed area in (1); (3) Olenellus nevadensis (Walcott, 1910) (UCR 10/3239); (4,5) Hyolithes whitei Resser, 1938 (UCR 10/2340, 10125/12, respectively); (6) Olenellus nevadensis (Walcott, 1910) and Paterina prospectensis (Walcott, 1884) $($ UCR 10). Scale bars $=2$ $\mathrm{mm}(\mathbf{1}, \mathbf{3 - 6}) ; 200 \mu \mathrm{m}(\mathbf{2})$.

with broad shallow sulcus. Shell surface marked by prominent radial ribs and weak concentric growth lines. Radial ribs originating at 1/5-1/7 valve length from posterior margin, widening gradually to margin with increment; total number of ribs 40-140; new ribs appearing by intercalation and separated by interspaces. Ribbing impressed on internal molds. Cardinal area of ventral valve unknown except that its plane extends backward at angle of $\sim 10^{\circ}$ or $15^{\circ}$ to plane of shell margin.

Materials.-Three ventral valves (UCR 10/2019B, 7307-13, and 7307/5) recovered from the Cadiz Formation.

Remarks.-Species of Wimanella are characterized by their smooth nonplicate shells (that Walcott previously referred to Billingsella Hall and Clarke, 1892). Wimanella is known from several lower to middle Cambrian areas, including North America, Australia, Siberia, and eastern China (e.g., Mount, 1974b; Roberts and Jell, 1990; Benedetto and Foglia, 2012). The species from the Cadiz Formation was previously regarded as Nisusia fulleri by Mount (1981), however, they differ significantly in that $W$. highlandensis is more trapezoidal in outline, and $N$. fulleri has thicker striae and a more elevated umbo. Wimanella tricavata Roberts and Jell, 1990 from the middle Cambrian Coonigan Formation of New South Wales can be differentiated by its subequally biconvex shell profile, slightly auriculate outline, shallow dorsal sulcus, and indistinct cardinal process (Roberts and Jell, 1990). Wimanella mollensis Benedetto and Foglia, 2012 from the middle Cambrian La Laja Formation of the Precordilleran Terrane can be differentiated by its deeper dorsal sulcus and less-developed radial striae (Benedetto and Foglia, 2012).

\section{Discussion and implication}

Biostratigraphic correlation.-Hazzard (1954) and Stewart (1970) have described the lower Cambrian sections in the studied area, and divided the lower Cambrian into five formations (Fig. 1.3). Trilobites from the Latham Shale indicate that it lies within the Bonnia-Olenellus Zone (Vaccari, 1988), which is approximately equivalent to the unnamed Stage 4 of the Cambrian Series 2. Only approximately the lower tenth of the Cadiz Formation is early Cambrian in age, whereas the major part belongs to the middle Cambrian and biozonation still needs further biostratigraphical study (Mount, 1980; Waggoner and Collins, 1995).

Other parts of Laurentia.-The Pioche Shale in Nevada spans the early-middle Cambrian boundary (e.g., Merriam, 1964; Rowell, 1980; Lieberman, 2003) (Fig. 1.3). This boundary is defined by the extinction of olenelloid trilobites (Palmer, 1998). Besides, the shift of $\delta^{13} \mathrm{C}$ and $\delta^{34} \mathrm{~S}$ isotope values also 


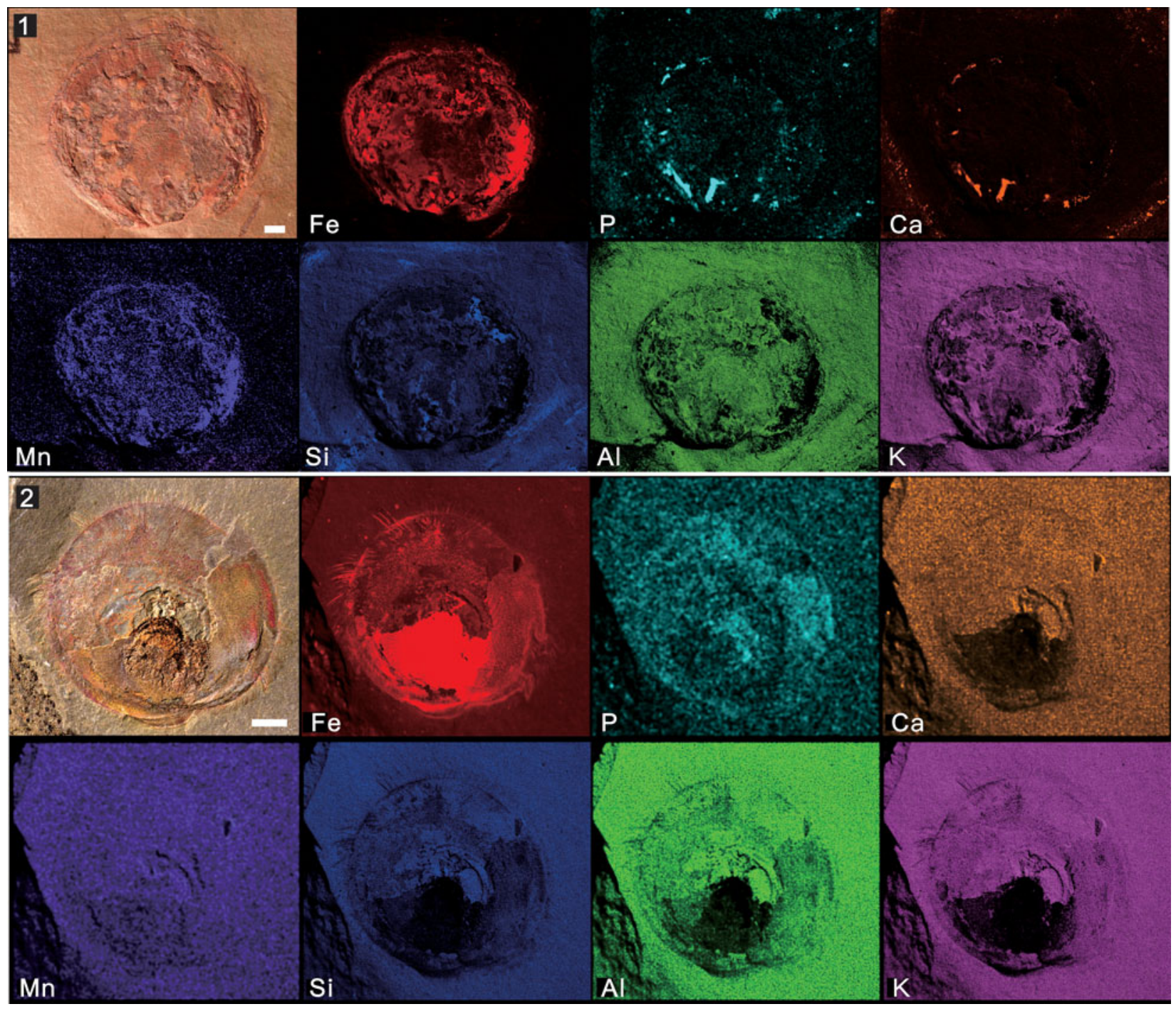

Figure 7. Micro X-ray florescence maps, showing elemental abundances of iron, phosphorus, calcium, manganese, silicon, aluminum, and potassium: (1) Mickwitzia occidens Walcott, 1908 from the Latham Shale (UCR 10/8/1, the same specimen displayed in Fig. 4.8); (2) Heliomedusa orienta Sun and Hou, 1987 from the Chengjiang Lagerstätte (ELI SJZ 2322). Scale bars $=2 \mathrm{~mm}$.

indicates the significant climatic and paleoceanographic changes around the early-middle Cambrian boundary (Montañez et al., 2000; Hough et al., 2006). Moore and Lieberman (2009) made a comprehensive study of the arthropod faunal composition and preservation of the Pioche Shale, suggesting that the fauna in the C-Shale Member of the Pioche Shale is similar to the Latham Shale of the Marble Mountains of southern California. Moreover, among the abundant brachiopod taxa from the Pioche Shale, both Hadrotreta primaea and Dictyonina pannula, which are also found in the Cadiz Formation, range from the Bonnia-Olenellus Zone into the pre-Albertella beds of the middle Cambrian (Rowell, 1980). Thus, it could be suggested that the Latham Shale and Cadiz Formation witnessed the transition from the early to middle Cambrian, which are quite comparable to the successive Pioche Shale (the Latham Shale correlates with the early Cambrian part, whereas the Cadiz Formation correlates with the middle Cambrian part).

The fauna of the Latham Shale and Cadiz Formation also correlate with the Forteau Formation of southern Labrador and western Newfoundland, Canada (Skovsted et al., 2017). Both the Latham Shale and the Forteau Formation contain paterinids, kutorginids, and problematic mickwitziids (represented by Mickwitzia occidens from the Latham Shale and Setatella significans Skovsted et al., 2010 from the Forteau Formation). At the generic level, the Forteau Formation yields Hadrotreta, which is also represented in the Cadiz Formation, and this extends the range of Hadrotreta from the early Cambrian to the middle Cambrian. Olenellid trilobites recovered from the Forteau Formation indicate that it lies entirely within the Bonnia-Olenellus Zone (Knight, 1991, 2013; Knight et al., 2017).

South Australia.-The fauna of the Latham Shale and Cadiz Formation is most comparable to that of the Coonigan Formation, western New South Wales (Roberts and Jell, 1990). Both faunas contain four brachiopod genera: Hadrotreta, Dictyonina, Nisusia, and Wimanella. Roberts and Jell (1990) noted that the brachiopod fauna (at least at the generic level) from the Coonigan Formation can be correlated with the brachiopod fauna described by Rowell (1980) from the early- 


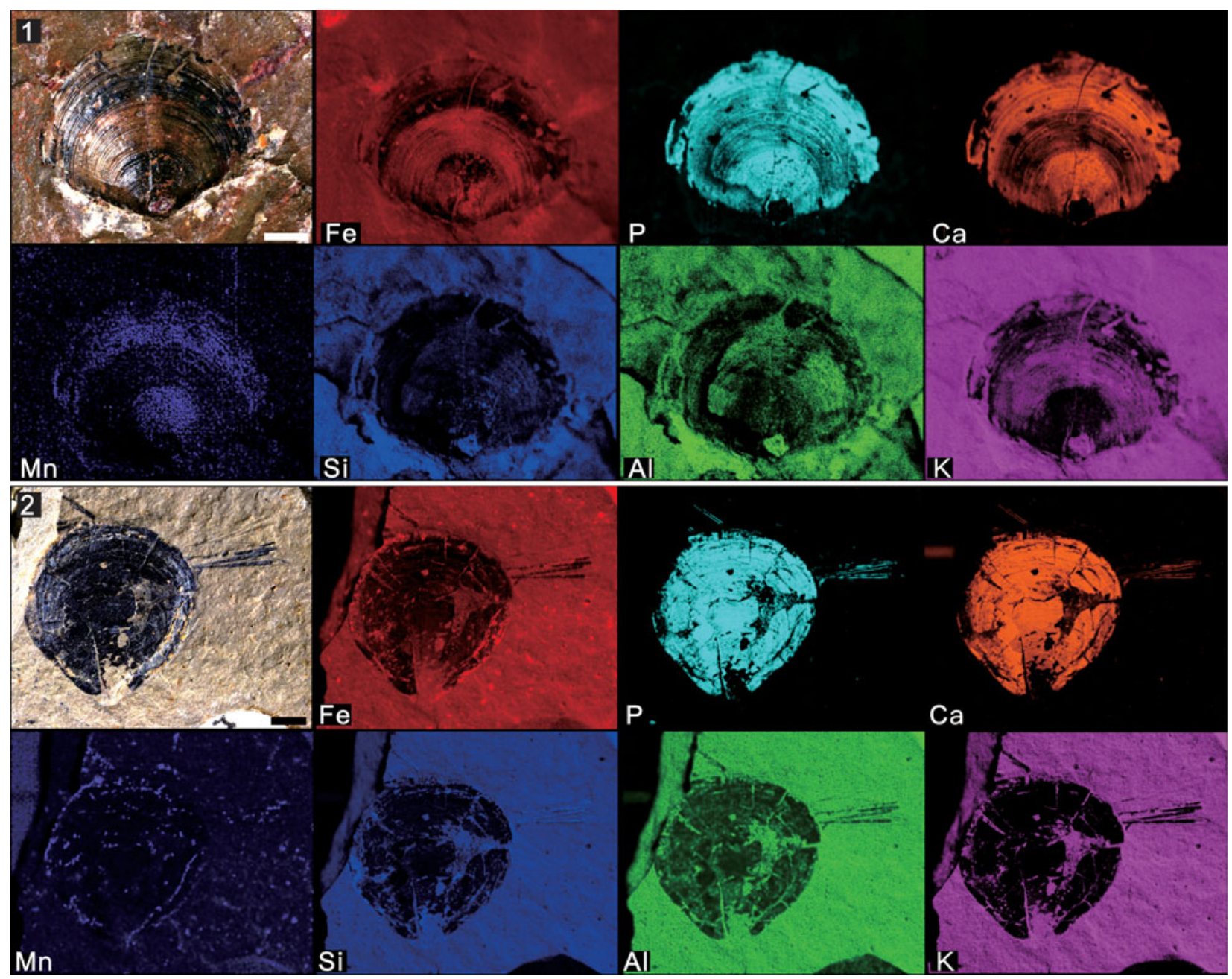

Figure 8. Micro X-ray florescence maps, showing elemental abundances as in (7): (1) Paterina prospectensis (Walcott, 1884) (UCR 10/2006, the same specimen displayed in Fig. 3.3); (2) brachiopod individual with possible Sphenothallus attached (UCR 7002/301, the same specimen displayed in Fig. 6.1). Scale bars =2 mm.

middle Cambrian boundary beds of the Pioche Shale in central Nevada. The precise stratigraphic ranges of brachiopods from the Coonigan Formation are poorly constrained, and it is thus possible that they might have a long stratigraphic range not appropriate for detailed biostratigraphic correlation (Brock and Percival, 2006). Percival and Kruse (2016) suggested that the brachiopod fauna in the Coonigan Formation is of stage 4 to possible early stage 5 age, which could be correlated with the Latham Shale and Cadiz Formation.

Broad correlation between South Australia and Laurentia is also made possible by the occurrence of Mickwitzia in both regions. In the Arrowie Basin and on the Stuart Shelf, occurrences of Mickwitzia are restricted to the Dailyatia odyssei Biozone (Betts et al., 2017). Mickwitzia occidens occurs both in the Indian Springs Lagerstätte (the Poleta Formation) in Nevada, and in the Latham Shale in California, which is of Nevadella Biozone to Bonnia-Olenellus Zone in age (English and Babcock, 2010; Butler et al., 2015). Mickwitzia muralensis occurs in the Mural Formation belonging to the Nevadella Zone with the boundary to the overlying Bonnia-Olenellus Zone (Balthasar, 2004; Skovsted et al., 2021). Thus, these occurrences support tentative correlation of the Nevadella to Bonnia-Olenellus zones in Laurentia with the Dailyatia odyssei Zone in South Australia. Recovery of better-preserved Mickwitzia specimens from South Australia and Laurentia would allow for accurate species identification and could permit more robust correlations in the future.

International correlation of the lower-middle Cambrian boundary interval (Series 2-3, Stage 4-5) is still under discussion, and more detailed biostratigraphic work and application of multiproxy methods will be required before confident international correlation can be attempted. The extent that brachiopods can contribute to international biostratigraphic correlation in the Cambrian boundary interval (Series 2-3, Stage 4-5) still needs to be tested.

Preservation.-Although the brachiopod fauna is not as diverse as that from other Lagerstätten (e.g., the Chengjiang and Guanshan biota), the fauna of the Latham Shale and Cadiz Formation is unique in its different preservational bias (Figs. 7-10). Three modes of preservation can be documented.

The first type is the replication of iron oxide films presented in Mickwitzia occidens, which is remarkably similar to the overall preservation of its close relative Heliomedusa orienta 


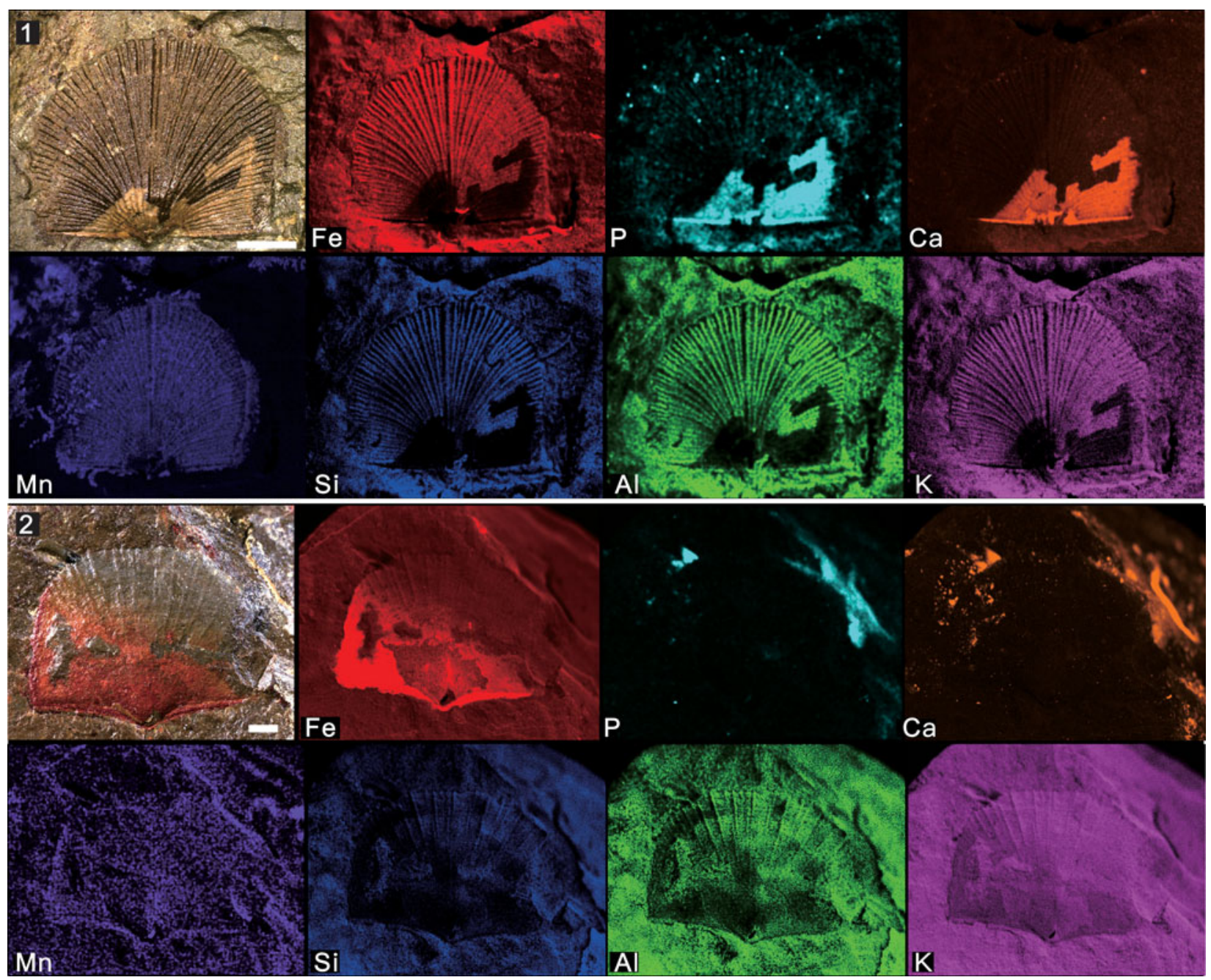

Figure 9. Micro X-ray florescence maps, showing elemental abundances as in (7): (1) Nisusia fulleri Mount, 1981 from the Latham Shale (UCR 10/2031, the same specimen displayed in Fig. 5.1); (2) Wimanella highlandensis (Walcott, 1886) from the Cadiz Formation (UCR 10/2019A). Scale bars $=2 \mathrm{~mm}$.

from the Chengjiang Lagerstätte (Figs. 7, 10.1) (Liang et al., 2020a, b). The shells from both South China and Laurentia are preserved by pyrite (with a reddish-brown color), which was later pseudomorphed by iron oxides (Gabbott et al., 2004). The lack of sulphur has been interpreted as resulting from subsequent alteration of pyrite from iron oxides (Gabbott et al., 2004). It is significant that calcium was not detected in these fossils (with presumed organophosphatic hard parts); a likely interpretation of this fact is that the alteration of pyrite to iron oxide released small quantities of sulfuric acid, which would have leached the calcium from carbonates and phosphates (Gabbott et al., 2004).

The shells of linguliforms, including Paterina, Hadrotreta, and Dictyonina, not only exhibit well-defined shell ornament and nicely profiled valves, but also preserve their calcium phosphatic hard shells, distinguished by their dark color with high contrast to the gray-green, somewhat weathered, reddish shale (Figs. 8, 10.2). They were notably enriched in chemical components by calcium and phosphorus, with high elemental contrast to the matrix in both mapping results and elemental counting data. This is highly different from the preservation of the
Chengjiang and Guanshan Lagerstätten, in which most phosphatic fossils are preserved by pyrite, and later replaced by iron oxides as mentioned above (Zhang et al., 2020a, b).

The carbonate-shelled rhynchonelliforms reveal an unusual preservation mode. Unlike the specimen of Mickwitzia occidens, iron is not concentrated on the shell, but has a relatively even distribution on both the fossil and the host rock (Figs. 9, 10.3). Furthermore, Nisusia fulleri displays a distinctive preservation in that the post-lateral part of the shell include calcium and phosphorus (Fig. 9.1), which remains problematic. One possible explanation is that this phosphorus could derive from the sedimentary environment during late diagenesis and result in secondary phosphatization. Nevertheless, another speculative interpretation is more challenging: both Cambrian rhynchonelliform and linguliform lineages included mineralization of calcium phosphate, followed by morphology differentiation and disparity. As the reconstruction of brachiopod phylogeny based on the study of their molecular/genetic rRNA characteristics demonstrates that the divergence between brachiopods with carbonate and phosphate shells occurred $\sim 570$ million years ago, in the Late Ediacaran (Cohen and Weydman, 2005), 


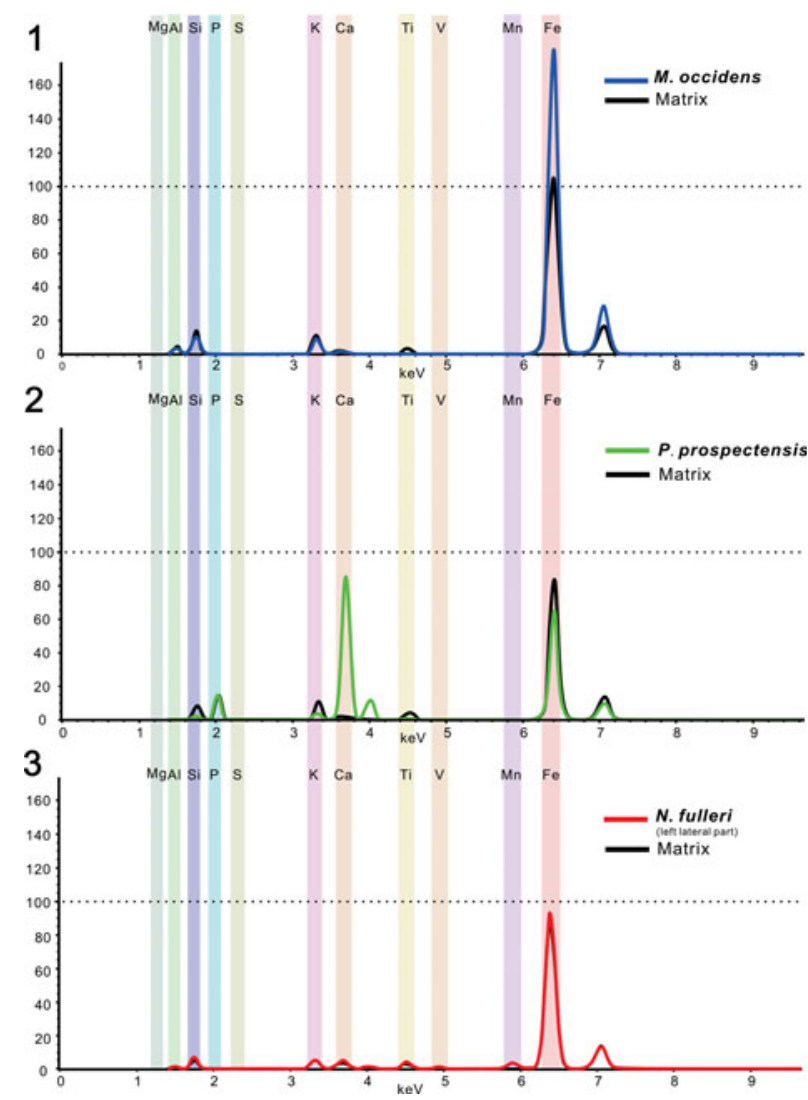

Figure 10. Mean $\mu$-XRF spectra and main elemental contributions from specimens of: (1) Mickwitzia occidens Walcott, 1908 (UCR 10/8/1); (2) Paterina prospectensis (Walcott, 1884) (UCR 10/2006); (3) left lateral part of Nisusia fulleri Mount, 1981 (UCR 10/2031)

hence the two parallel lineages of brachiopod ancestors already existed by the beginning of the Cambrian. They lacked mineral skeletons, and one of the lineages quickly constructed external coverings from calcium phosphate and another from calcium carbonate (Ushatinskaya, 2008). The case of Nisusia fulleri is perhaps comparable to composition of the linguliform brachiopod Eoobolus Matthew, 1902 from the lower Cambrian Mural Formation-the original shell of Eoobolus contained microstructural small calcareous grains that were incorporated into organic-rich layers alongside apatite (Balthasar, 2007) —and might also be reminiscent of Salanygolina obliqua Ushatinskaya, 1987 from the lower Cambrian of Mongolia, in which the laminar phosphatic secondary shell layer is composed of hexagonal prisms with organic sheaths representing calcite fibers (Holmer et al., 2009). This seems to suggest that the mixed organophosphatic-calcareous shells were relatively common at that time. Although the shell composition of earliest brachiopods still remains uncertain, the information from both shale- and limestone-hosted material could give us clues for what to look for and how to look for it.

The systematic taphonomic bias for the Latham Shale and Cadiz Formation has significant implications for understanding the original faunal community assemblage, specifically in regard to shell composition of the early Cambrian articulate brachiopods. Accordingly, further stratigraphic sampling and mineralogical studies of the lower Cambrian section from the
Latham Shale to the Cadiz Formation could yield additional useful information on the diagenetic relationship. This would also help determine the role of weathering on the preservation of these faunas and further clarify the degree of similarity to the preservation of the Chengjiang Biota, and hence the significance of global environmental changes on fossil preservation.

The transition from the Cambrian Evolutionary Fauna (CEF) to the Paleozoic Evolutionary Fauna (PEF). - The 'Cambrian Explosion' and the 'Great Ordovician Biodiversification Event' (GOBE) were the two most significant evolutionary events in the history of Paleozoic marine life. Based on multivariate statistical analyses, Sepkoski (e.g., 1981, 1991) defined three evolutionary faunas: a trilobite-dominated Cambrian Evolutionary Fauna (CEF), a brachiopod-dominated Paleozoic Evolutionary Fauna (PEF), and a mollusk-dominated Mesozoic-Cenozoic (or 'Modern') Evolutionary Fauna (MEF) (Fig. 11). The CEF is associated with (or is responsible for) the radiations of the early Cambrian Period and the diversity plateau of the middle-late Cambrian; the PEF is associated with the Ordovician radiations and the long Paleozoic equilibrium (Sepkoski, 1981). Although the PEF, represented mainly by the Ordovician biodiversification of families, grows in importance, it already presented a revolution of body plans during the Cambrian (Servais and Harper, 2018; Harper et al., 2019).

The brachiopod association in the Latham Shale is represented by Paterina prospectensis, Mickwitzia occidens, and Nisusia fulleri. Mickwitzia only occurred in the strata of the early Cambrian, and probably represents a stem-group brachiopod (Holmer and Popov, 2007; Butler et al., 2015; Liang et al., 2020a, b). Paterina has been of abiding interest since it was first separated taxonomically from the kutorginids (Beecher, 1891), and the group has already been recognized as among the oldest metazoans represented by biomineralized remains in the geological record (Williams et al., 1998). Nisusia is one of the most common early-middle Cambrian rhynchonelliform brachiopods, with a stratigraphic range from the unnamed Cambrian Stage 3 to the Miaolingian (Drumian) (Holmer et al., 2019). The abundant olenellid trilobites and hyolithids in this fauna (Fig. 6) (Mount, 1980), together with brachiopod species commonly seen in early Cambrian time, comprise important components of the CEF, like the Chengjiang and Guanshan Lagerstätten, which were dominated by trilobites and nonarticulated brachiopods (Zhao et al., 2010; Chen et al., 2018, 2021).

Three other species-Hadrotreta primaea, Dictyonina pannula, and Wimanella highlandensis - have been collected from the upper Cadiz Formation. Hadrotreta is a widespread taxon that achieved an almost cosmopolitan distribution at low latitudes during Miaolingian time (Popov et al., 2015). Dictyonina is a relatively common, cosmopolitan component in Drumian-Guzhangian linguliform faunas. The Orthida are one of the main components of the PEF (Zhan and Harper, 2006), and previous reports of Wimanella from the USA, Greenland, Australia, and Argentina are of middle Cambrian age (Bell, 1941; Howell, 1943; Roberts and Jell, 1990; Benedetto and Foglia, 2012). These three brachiopod species of middle Cambrian age indicate that this fauna likely presents the earliest onset of the PEF. 

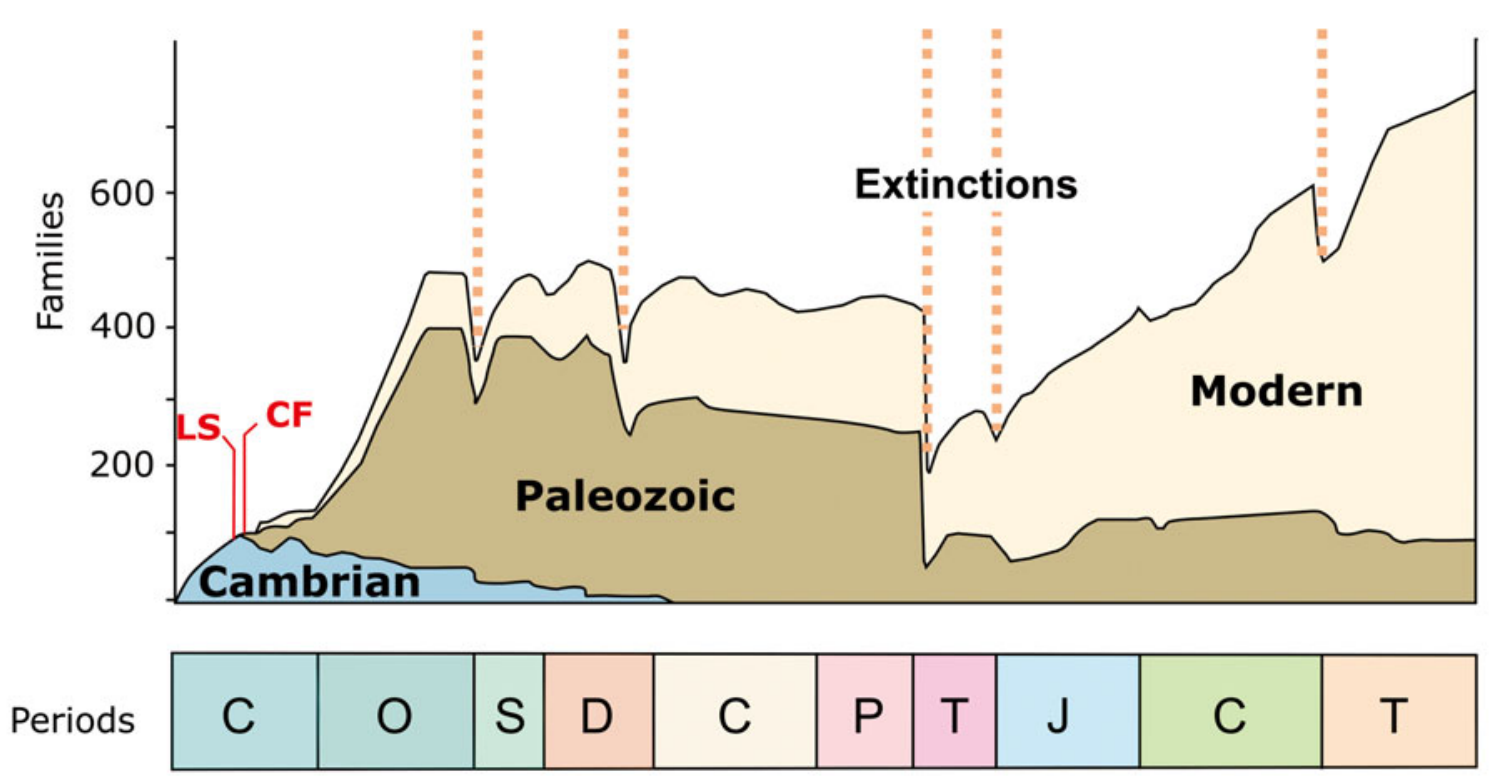

Figure 11. The classic Sepkoski diversity curve of marine invertebrate families through Phanerozoic time, documenting the Cambrian, Paleozoic, and Modern Evolutionary Faunas, and the 'Big Five' mass extinctions (dashed vertical lines) of marine invertebrates (modified from Sepkoski, 1981; Harper, 2006). Solid red vertical lines represent the fauna of the Latham Shale (LS) and Cadiz Formation (CF). Geological periods (left to right): $\mathrm{C}=\mathrm{Cambrian} ; \mathrm{O}=\mathrm{Ordovician} ; \mathrm{S}=\mathrm{Silurian}$; $\mathrm{D}=$ Devonian; $\mathrm{C}=$ Carboniferous; $\mathrm{P}=$ Permian; $\mathrm{T}=$ Triassic; $\mathrm{J}=\mathrm{Jurassic} ; \mathrm{C}=$ Cretaceous; $\mathrm{T}=$ Tertiary .

The organophosphatic linguliformeans had already radiated during the middle and late Cambrian and represented an integral part of the CEF. The acrotretides and the linguloids were significant components of the fauna and diversified during the middle and late Cambrian (Harper and Rong, 2001). The Cambrian articulated rhynchonelliformean fauna since Epoch 2 and the Miaolingian boundary is generally of low diversity. The Kutorginida, including the families Kutorginidae and Nisusiidae, are the most abundant early Cambrian nonarticulated rhynchonelliformean brachiopods and became extinct at the end of the middle Cambrian. Generally, the typical Ordovician brachiopod fauna is taxonomically dominated by the articulated Orthida and Strophomenida (Harper et al., 1999) that usually account for two-thirds of the total fauna. The occurrence of the transition from nonarticulated Kutorginida to articulated Orthida within these two brachiopod faunas possibly indicates the establishment of the more typical brachiopod components of the early PEF.

There remains some turnover in taxonomic composition within each of the evolutionary faunas during their periods of dominance, and transition from the CEF toward the PEF in one section could be somewhat difficult to correlate worldwide. The material from the Latham Shale and Cadiz Formation possibly provides evidence that the change of evolutionary faunas could be detected among brachiopods collected from one section. More material from the studied area would enable a comprehensive quantitative analysis of the transition between evolutionary faunas and related paleographic and paleoenvironmental implications.

\section{Acknowledgments}

The present research was financially supported by the National Natural Science Foundation of China (NSFC 41720104002, 41890844, 41425008, and 41621003), by the Strategic Priority Research Program of Chinese Academy of Sciences (XDB26000000), and by 111 Project (D17013). The research of LEH is supported by the Swedish Research Council (VR project no. 2018-03390) and by a Zhongjian Yang Scholarship from the Department of Geology, Northwest University, Xi' an. YL sincerely acknowledges the China Scholarship Council (no. 202006970023) for one year of research as a visiting $\mathrm{PhD}$ student with LEH at Uppsala University. We thank N. Hughes and L. English (University of California, Riverside) for their kind permission and assistance with the loan of brachiopod specimens. Associate Editor C. Sproat and reviewers R. Freeman and C.B. Skovsted are greatly appreciated for their positive comments and insightful reviews.

\section{References}

Aksarina, N.A., 1975. Brachiopods, in [Lower Palaeozoic Stratigraphy and Fauna of the Northern Slopes of the Turkestan and Alay Ranges]: Trudy Instituta Geologii i Geofiziki, Akademiya Nauk SSSR, Sibirskoe Otdelenie, p. 91-100. [in Russian]

Balthasar, U., 2004, Shell structure, ontogeny and affinities of the lower Cambrian bivalved problematic fossil Mickwitzia muralensis Walcott, 1913: Lethaia, v. 37, p. 381-400, https://doi.org/10.1080/00241160410002090.

Balthasar, U., 2007, An early Cambrian organophosphatic brachiopod with calcitic granules: Palaeontology, v. 50, p. 1319-1325, https://doi.org/10.1111/ j.1475-4983.2007.00729.x. 
Beecher, C.E., 1891, Development of the Brachiopoda: American Journal of Science, ser. 3, v. 41, p. 343-357.

Bell, W.C., 1941, Cambrian Brachiopoda from Montana: Journal of Paleontology, v. 15 , p. $193-255$.

Benedetto, J.L., and Foglia, R.D., 2012, Lower and middle Cambrian rhynchonelliform brachiopods from the Precordillera Terrane of Argentina: Journal of Paleontology, v. 86, p. 273-281, https://doi.org/10.1666/10-115.1.

Betts, M.J., Paterson, J.R., Jago, J.B., Jacquet, S.M., Skovsted, C.B., Topper, T.P., and Brock, G.A., 2017, Global correlation of the early Cambrian of South Australia: Shelly fauna of the Dailyatia odyssei Zone: Gondwana Research, v. 46, p. 240-279, https://doi.org/10.1016/j.gr.2017.02.007.

Billings, E., 1861, Palaeozoic fossils containing descriptions and figures of new or little known species of organic remains from the Silurian rocks: Geological Survey of Canada, Palaeozoic Fossils, v. 1, p. 1-24.

Billings, E., 1872, On some fossils from the primordial rocks of Newfoundland: Canadian Naturalist and Quarterly Journal of Science, v. 6, p. 465-479.

Briggs, D.E.G., and Mount, J.D., 1982, The occurrence of the giant arthropod Anomalocaris in the lower Cambrian of southern California and the overal distribution of the genus: Journal of Paleontology, v. 56, p. 1112-1118.

Brock, G.A., and Cooper, B.J., 1993, Shelly fossils from the early Cambrian (Toyonian) Wirrealpa, Aroona Creek, and Ramsay limestones of South Australia: Journal of Paleontology, v. 67, p. 758-787.

Brock, G.A., and Percival, I.G., 2006, Cambrian stratigraphy and faunas at Mount Arrowsmith, northwestern New South Wales: Memoirs of the Association of Australasian Palaeontologists, v. 32, p. 75-101.

Butler, A.D., Streng, M., Holmer, L.E., and Babcock, L.E., 2015, Exceptionally preserved Mickwitzia from the Indian Springs Lagerstätte (Cambrian Stage 3), Nevada: Journal of Paleontology, v. 89, p. 933-955, https://doi.org/10.1017/ jpa.2016.8.

Chen, F.Y., Zhang, Z.-F., Betts, M.J., Zhang, Z.L., and Liu, F., 2018, First report on Guanshan Biota (Cambrian Stage 4) at the stratotype area of Wulongqing Formation in Malong County, eastern Yunnan: Geoscience Frontiers, v. 10, p. 1459-1476, https://doi.org/10.1016/j.gsf.2018.09.010.

Chen, F.Y., Brock, G.A., Zhang, Z.L., Laing, B., Ren, X.Y., and Zhang, Z.-F., 2021, Brachiopod-dominated communities and depositional environment of the Guanshan Konservat-Lagerstätte, eastern Yunnan, China: Journal of the Geological Society, v. 178, jgs2020-043, https://doi.org/10.1144/ jgs2020-043.

Clark, C.W., 1921, Lower and middle Cambrian formations of the Mojave Desert: University of California Publications, Department of Geological Sciences, v. 13, p. 1-7.

Cohen, B.L., and Weydmann, A., 2005, Molecular evidence that phoronids are a subtaxon of brachiopods (Brachiopoda: Phoronata) and that genetic divergence of metazoan phyla began long before the early Cambrian: Organisms Diversity \& Evolution, v. 5, p. 253-273, https://doi.org/10.1016/j.ode.2004.12.002.

Conway Morris, S., and Peel, J.S., 2010, New palaeoscolecidan worms from the lower Cambrian: Sirius Passet, Latham Shale and Kinzers Shale: Acta Palaeontologica Polonica, v. 55, p. 141-156, https://doi.org/10.4202/app. 2009.0058.

Cooper, G.A., 1942, New genera of North American brachiopods: Journal of the Washington Academy of Sciences, v. 32, p. 228-235.

Cooper, G.A., 1951, New brachiopods from the lower Cambrian of Virginia: Journal of the Washington Academy of Sciences, v. 41, p. 4-8.

Cordie, D.R., Dornbos, S.Q., and Marenco, P.J., 2019, Increase in carbonate contribution from framework-building metazoans through early Cambrian reefs of the Western Basin and Range, USA: Palaios, v. 34, p. 159-174, https://doi.org/10.2110/palo.2018.085.

Darton, N.H., 1907, Discovery of Cambrian rocks in southeastern California: The Journal of Geology, v. 15, p. 470-473.

Devaere, L., Holmer, L.E., Clausen, S., and Vachard, D., 2015, Oldest mickwitziid brachiopod from the Terreneuvian of southern France: Acta Palaeontologica Polonica, v. 60, p. 755-768, https://doi.org/10.4202/app.00021.2013.

Duméril, A.M.C., 1806, Zoologie analytique, ou méthode naturelle de classification des animaux: Paris, Allais, $344 \mathrm{p}$.

Durham, J.W., 1978, A lower Cambrian new eocrinoid: Journal of Paleontology, v. 52, p. 195-199.

English, A.M., and Babcock, L.E., 2010, Census of the Indian Springs Lagerstätte, Poleta Formation (Cambrian), western Nevada, USA: Palaeogeography, Palaeoclimatology, Palaeoecology, v. 295, p. 236-244, https://doi. org/10.1016/j.palaeo.2010.05.041.

Gabbott, S.E., Hou, X.G., Norry, M.J., and Siveter, D.J., 2004, Preservation of early Cambrian animals of the Chengjiang biota: Geology, v. 32, p. 901904, https://doi.org/10.1130/G20640.1

Gaines, R.R., and Droser, M.L., 2002, Depositional environments, ichnology, and rare soft-bodied preservation in the lower Cambrian Latham Shale East Mojave, in Corsetti, F.A., ed., Proterozoic-Cambrian of the Great Basin and Beyond: Field Trip Guidebook and Volume Prepared for the Annual Pacific Section SEPM Fall Field Trip, 15-17 November 2002, Shoshone, California: Fullerton, California, SEPM Pacific Section, p. 153-164.
Gorjansky, V.J., 1969, [Inarticulate brachiopods of the Cambrian and Ordovician of the northwest Russian Platform]: Ministerstvo Geologii RSFSR, Severo-Zapadnoe Territorialnoe Geologicheskoe Upravlenie, v. 6, p. 1-173. [in Russian]

Gorjansky, V.J., and Popov, L.E., 1985, [Morphology, systematic position and origin of the inarticulate brachiopods with calcareous shells]: Paleontologicheskiy Zhurnal, v. 3, p. 3-14. [in Russian]

Hall, J., and Clarke, J.M., 1892, Palaeontology of New York, Volume 8, Part 1, An Introduction to the Study of the Genera of Palaeozoic Brachiopoda: Albany, New York State Geological Survey, 367 p.

Harper, D.A.T., 2006, The Ordovician biodiversification: Setting an agenda for marine life: Palaeogeography, Palaeoclimatology, Palaeoecology, v. 232, p. 148-166, https://doi.org/10.1016/j.palaeo.2005.07.010.

Harper, D.A.T., and Rong, J.-Y., 2001, Palaeozoic brachiopod extinctions, survival and recovery: Patterns within the rhynchonelliformeans: Geological Journal, v. 36, p. 317-328, https://doi.org/10.1002/gj.897.

Harper, D.A.T., Rong, J.Y., and Sheehan, P.M., 1999, Ordovician diversity patterns in early rhynchonelliform (protorthide, orthide and strophomenide) brachiopods: Acta Universitatis Carolinae Geologia, v. 43, p. 351-353.

Harper, D.A.T., Cascales-Miñana, B., and Servais, T., 2019, Early Palaeozoic diversifications and extinctions in the marine biosphere: A continuum of change: Geological Magazine, v. 157, p. 5-21, https://doi.org/10.1017/ S0016756819001298.

Havlíček, V., 1977, Brachiopods of the order Orthida in Czechoslovakia: Rozpravy Ústředního Ústavu Geologického, v. 44, p. 1-327.

Hazzard, J.C., 1954, Rocks and structure of the northern Providence Mountains, San Bernardino County, California: California Division of Mines and Geology Bulletin, v. 170, p. 27-35.

Hazzard, J.C., and Mason, J.F., 1936, Middle Cambrian formations of the Providence and Marble mountains, California: Geological Society of America Bulletin, v. 47, p. 229-240.

Hollingsworth, J.S., 2011, Lithostratigraphy and biostratigraphy of Cambrian Stage 3 in western Nevada and eastern California: Museum of Northern Arizona Bulletin, v. 67, p. 26-42.

Hollingsworth, J.S., and Babcock, L.E., 2011, Base of Dyeran Stage (Cambrian Stage 4) in the middle member of the Poleta Formation, Indian Springs Canyon, Montezuma Range, Nevada: Museum of Northern Arizona Bulletin, v. 67, p. $256-262$

Holmer, L.E., and Popov, L.E., 1994, Revision of the type species of Acrotreta and related lingulate brachiopods: Journal of Paleontology, v. 68, p. 433450.

Holmer, L.E., and Popov, L.E., 2007, Organophosphatic bivalve stem-group brachiopods, in Williams, A., Brunton, C.H.C., and Carlson, S.J., eds., Treatise on Invertebrate Paleontology, Part H, Brachiopoda (Revised), Volume 6: Boulder, Colorado and Lawrence, Kansas, Geological Society of America (and University of Kansas Press), p. H2581-H2590.

Holmer, L.E., Popov, L.E., and Wrona, R., 1996, Early Cambrian lingulate brachiopods from glacial erratics of King George Island (South Shetland Islands), Antarctica: Palaeontologia Polonica, v. 55, p. 37-50.

Holmer, L.E., Skovsted, C.B., and Williams, A., 2002, A stem group brachiopod from the lower Cambrian: Support for a Micrina (halkieriid) ancestry: Palaeontology, v. 45, p. 875-882, https://doi.org/10.1111/1475-4983. 00265 .

Holmer, L.E., Stolk, S.P., Skovsted, C.B., Balthasar, U., and Popov, L.E., 2009, The enigmatic early Cambrian Salanygolina: A stem group of rhynchonelliform chileate brachiopods?: Palaeontology, v. 52, p. 1-10, https://doi.org/ 10.1111/j.1475-4983.2008.00831.x.

Holmer, L.E., Popov, L.E., Ghobadi Pour, M., Zhang, Z.L., and Zhang, Z.-F., 2017, Unusual pitted Ordovician brachiopods from the East Baltic: The significance of coarsely pitted ornamentations in linguliforms: Papers in Palaeontology, v. 3, p. 387-399, https://doi.org/10.1002/spp2.1080.

Holmer, L.E., Kebria-ee Zadeh, M.-R., Popov, L.E., Ghobadi Pour, M., Álvaro, J.J., Hairapetian, V., and Zhang, Z.-F., 2019, Cambrian rhynchonelliform nisusioid brachiopods: Phylogeny and distribution: Papers in Palaeontology, v. 5 , p. $559-575$, https://doi.org/10.1002/spp2.1255.

Hough, M.L., Shields, G.A., Evins, L.Z., Strauss, H., Henderson, R.A., and Mackenzie, S., 2006, A major sulphur isotope event at c. 510 Ma: A possible anoxia-extinction-volcanism connection during the early-middle Cambrian transition: Terra Nova, v. 18, p. 257-263, https://doi.org/10. 1111/j.1365-3121.2006.00687.x.

Howell, B. F., 1943, Faunas of the Cambrian Cloud Rapids and Treytown Pond formations of northern Newfoundland: Journal of Paleontology, v. 17, p. 236-247.

Knight, I., 1991, Geology of Cambro-Ordovician rocks in the Port Saunders (NTS 12I/11), Castor River (NTS 12I/15), St. John Island (NTS 12I/14), and Torrent River (NTS 12I/10) map areas: Newfoundland Department of Mines and Energy, Mineral Development Division, Report 91-4, 138 p.

Knight, I., 2013, The Forteau Formation, Labrador Group, in Gros Morne National Park: A preliminary reassessment of its stratigraphy and lithofacies: 
Current Research, Newfoundland and Labrador Department of Natural Resources, Geological Survey, Report 13-1, p. 267-300.

Knight, I., Boyce, W.D., Skovsted, C.B., and Balthasar, U., 2017, The lower Cambrian Forteau Formation, southern Labrador and Great Northern Peninsula, western Newfoundland: Lithostratigraphy, trilobites, and depositional setting: Government of Newfoundland and Labrador, Department of Natural Resources, Geological Survey, St. John\&rsquo;s, Occasional Papers 2017-01, 72 p.

Koneva, S.P., 1986, [A new family of Cambrian inarticulate brachiopods]: Paleontologicheskiy Zhurnal, p. 49-55. [in Russian]

Kruse, P.D., 1990, Cambrian palaeontology of the Daly Basin: Northern Territory Geological Survey, v. 7, 58 p.

Kuhn, O., 1949, Lehrbuch der Paläozoologie: Stuttgart, Germany, Schweizerbart, $326 \mathrm{p}$

Kutorga, S.S., 1848, Ueber die Brachiopoden-Familie der Siphonotretaceae: Russisch-Kaiserliche Mineralogische Gesellschaft zu St. Petersbourg, Verhandlungen, v. 1847 , p. $250-286$.

Laurie, J., 1987, The musculature and vascular systems of two species of Cambrian Paterinide (Brachiopoda): BMR Journal of Australian Geology \& Geophysics, v. 10, p. 261-265.

Laurie, J., 2000, Class Paterinata, in Kaesler, R.L., ed., Treatise on Invertebrate Paleontology, Part H, Brachiopoda (Revised), Volume 2: Boulder, Colorado, and Lawrence, Kansas, Geological Society of America (and University of Kansas Press), p. H147-H157.

Liang, Y., Holmer, L.E., Hu, Y.Z, and Zhang, Z.-F., 2020a, First report of brachiopods with soft parts from the lower Cambrian Latham Shale (Series 2, Stage 4), California: Science Bulletin, v. 65, p. 1543-1546, https://doi.org/ 10.1016/j.scib.2020.05.001.

Liang, Y., Holmer, L.E., Skovsted, C.B., Duan, X.-L., and Zhang, Z.-F., 2020b, Shell structure, ornamentation and affinity of the problematic early Cambrian brachiopod Heliomedusa orienta: Lethaia, v. 53, p. 574-587, https://doi.org/10.1111/let.12379.

Lieberman, B.S., 2003, A new soft-bodied fauna: The Pioche Formation of Nevada: Journal of Paleontology, v. 77, p. 674-690, https://doi.org/10. $1017 / \mathrm{S} 0022336000044413$.

Liñán, E., and Mergl, M., 1982, Lower Cambrian brachiopods of Sierra Morena, SW Spain: Boletín de la Real Sociedad Española de Historia Natural, Sección Geológica, v. 80, p. 207-220.

Linnarsson, J.G.O., 1869, Om några försteningar från Vestergötlands sandstenslager: Ovfersigt af Kongliga Vetenskaps-Akademiens Förhandlingar, v. 26, p. $337-357$.

Mason, J.F., 1935, Fauna of the Cambrian Cadiz Formation, Marble Mountains, California: Bulletin of the Southern California Paleontological Society, v. 34, p. 97-119.

Matthew, G.F., 1902, Ostracoda of the basal Cambrian rocks in Cape Breton: Canadian Record of Science, v. 8, p. 437-470.

McMenamin, M.A.S., 1986, The garden of Ediacara: Palaios, v. 1, p. 178-182.

McMenamin, M.A.S., 1992, Two new species of the Cambrian genus Mickwitzia: Journal of Paleontology, v. 66, p. 173-182.

Meek, F.B., 1873, Preliminary paleontological report, consisting of lists and descriptions of fossils, with remarks on the ages of the rocks in which they were found, etc.: U.S. Geological Survey of the Territories, 6th Annual Report, 1872, p. 429-518

Merriam, C.W., 1964, Cambrian rocks of the Pioche Mining District, Nevada: U.S. Geological Survey Professional Paper, v. 469, p. 1-59.

Montañez, I.P., Osleger, D.A., Banner, J.L., Mack, L.E., and Musgrove, M., 2000, Evolution of the $\mathrm{Sr}$ and $\mathrm{C}$ isotope composition of Cambrian oceans: GSA Today, v. 10, p. 1-7.

Moore, R.A., and Lieberman, B.S., 2009, Preservation of early and middle Cambrian soft-bodied arthropods from the Pioche Shale, Nevada, USA: Palaeogeography, Palaeoclimatology, Palaeoecology, v. 277, p. 57-62, https://doi.org/10.1016/j.palaeo.2009.02.014.

Mount, J.D., 1974a, Early Cambrian articulate brachiopods from the Marble Mountains, San Bernardino County, California: Bulletin of the Southern California Paleontological Society, v. 6, p. 47-52.

Mount, J.D. 1974b, Early Cambrian faunas from the Marble and Providence Mountains, San Bernardino County, California: Bulletin of the Southern California Paleontological Society, v. 6, p. 1-5.

Mount, J.D., 1976, Early Cambrian faunas from eastern San Bernardino County, California: Bulletin of the Southern California Paleontological Society, v. 8, p. 173-182.

Mount, J.D., 1980, Characteristics of early Cambrian faunas from eastern San Bernardino County, California: Southern California Paleontological Society Special Publications, v. 2, p. 19-29.

Mount, J.D., 1981, A new articulate brachiopod from the lower Cambrian Latham Shale, southeastern California: Bulletin of the Southern California Academy of Sciences, v. 80, p. 46-48.

Nelson, C., 1978, Late Precambrian-early Cambrian stratigraphic and faunal succession of eastern California and the Precambrian-Cambrian boundary: Geological Magazine, v. 115, p. 121-126.
Nemliher, J., 2001, The shell structure and mineralogy of Mickwitzia (Lingulata: Brachiopoda) from the lower Cambrian Kakumae beds of Estonia: Proceedings of the Estonian Academy of Sciences, Geology, v. 50, p. $43-50$.

Palmer, A.R., 1964, An unusual lower Cambrian trilobite fauna from Nevada: U.S. Geological Survey Professional Paper 483-F, p. 1-13.

Palmer, A.R., 1998, A proposed nomenclature for stages and series for the Cambrian of Laurentia: Canadian Journal of Earth Sciences, v. 35, p. 323-328.

Palmer, A.R., and R.B. Halley, 1979, Physical stratigraphy and trilobite biostratigraphy of the Carrara Formation (lower and middle Cambrian) in the southern Great Basin: U.S. Geological Survey Professional Paper, v. 1047, p. 1-139.

Percival, I.G., and Kruse, P.D., 2014, Middle Cambrian brachiopods from the southern Georgina Basin of central Australia: Memoirs of the Association of Australasian Palaeontologists, v. 45, p. 349-402.

Percival, I.G., and Kruse, P.D., 2016, Middle to late Cambrian (Stage 4-Jiangshanian) linguliform brachiopods and their biogeographic affinities: Palaeo Down Under 2, 11-15 July 2016, Adelaide, South Australia, Abstracts, no. $117,78$.

Popov, L.E., Holmer, L.E. and Gorjansky, V.J., 1996, Middle Cambrian lingulate brachiopods from the Tarbagatay Range, Kazakhstan: Acta Palaeontologica Polonica, v. 41, p. 299-317.

Popov, L.E., Holmer, L.E., Hughes, N.C., Ghobadi Pour, M., and Myrow, P.M., 2015, Himalayan Cambrian brachiopods: Papers in Palaeontology, v. 1, p. 345-399, https://doi.org/10.1002/spp2.1017.

Poulsen, C., 1932, The lower Cambrian faunas of East Greenland: Meddelelser om Grønland, v. 87, 66 p

Resser, C.E., 1938, Fourth contribution to nomenclature of Cambrian fossils: Smithsonian Miscellaneous Collections, v. 97, no. 10, 43 p.

Roberts, J., and Jell, P.A., 1990, Early middle Cambrian (Ordian) brachiopods of the Coonigan Formation, western New South Wales: Alcheringa, v. 14, p. 257-309, https://doi.org/10.1080/03115519008619059.

Rowell, A.J., 1965, Inarticulata, in Moore, R.E., ed., Treatise on Invertebrate Palaeontology, Part H, Brachiopoda, Volume 1: Boulder, Colorado, and Lawrence, Kansas, Geological Society of America (and University of Kansas Press), p. H260-H296.

Rowell, A.J., 1966, Revision of some Cambrian and Ordovician inarticulate brachiopods: University of Kansas Paleontological Contributions, v. 7, p. 1-36.

Rowell, A.J., 1977, Early Cambrian brachiopods from the southwestern Great Basin of California and Nevada: Journal of Paleontology, v. 51, p. 68-85.

Rowell, A.J., 1980, Inarticulate brachiopods of the lower and middle Cambrian Pioche Shale of the Pioche District, Nevada: University of Kansas Paleontological Contributions, v. 98, p. 1-25.

Rowell, A.J., and Henderson, R.A., 1978, New genera of acrotretids from the Cambrian of Australia and the United States: University of Kansas Paleontological Contributions, v. 93, p. 1-11.

Rowland, S.M., Oliver, L.K., and Hicks, M., 2008, Ediacaran and early Cambrian reefs of Esmeralda County, Nevada: Non-congruent communities within congruent ecosystems across the Neoproterozoic-Paleozoic boundary, in Duebendorfer, E.M., and Smith, E.I., eds., Field Guide to Plutons, Volcanoes, Faults, Reefs, Dinosaurs, and Possible Glaciation in Selected Areas of Arizona, California, and Nevada: Geological Society of America Field Guide 11, p. 83-100, https://doi.org/10.1130/2008.fld011(04).

Schmidt, F., 1888, Über eine neuentdeckte Untercambrische Fauna in Estland: Académie Impériale des Sciences de St.-Pétersbourg, Mémoires, ser. 7, v. 36 , p. $1-27$.

Schuchert, C., 1893, A classification of the Brachiopoda: American Geologist, v. 11, p. $141-167$.

Schuchert, C., and Cooper, G.A., 1932, Brachiopod genera of the suborders Orthoidea and Pentameroidea: Memoirs of the Peabody Museum of Natural History, v. 4, 270 p.

Sepkoski, J.J., Jr., 1981, A factor analytic description of the Phanerozoic marine fossil record: Paleobiology, v. 7, p. 36-53.

Sepkoski, J.J., Jr., 1991, A model for onshore-offshore change in faunal diversity: Paleobiology, v. 17, p. 58-77.

Servais, T., and Harper, D.A.T., 2018, The great Ordovician biodiversification event (GOBE): Definition, concept and duration: Lethaia, v. 51, p. 151164, https://doi.org/10.1111/let.12259.

Skovsted, C.B., and Holmer, L.E., 2003, The early Cambrian (Botomian) stem group brachiopod Mickwitzia from Northeast Greenland: Acta Palaeontologica Polonica, v. 48, p. 1-20.

Skovsted, C.B., and Holmer, L.E., 2005, Early Cambrian brachiopods from north-east Greenland: Palaeontology, v. 48, p. 325-345, https://doi.org/10. 1111/j.1475-4983.2005.00450.x.

Skovsted, C.B., and Holmer, L.E., 2006, The lower Cambrian brachiopod Kyrshabaktella and associated shelly fossils from the Harkless Formation, southern Nevada: GFF, v. 128, p. 327-337,

Skovsted, C.B., Brock, G.A., Holmer, L.E., and Paterson, J.R., 2009, First report of the early Cambrian stem group brachiopod Mickwitzia from East 
Gondwana: Gondwana Research, v. 16, p. 145-150, https://doi.org/10. 1016/j.gr.2009.02.002

Skovsted, C.B., Streng, M., Knight, I., and Holmer, L.E., 2010, Setatella significans, a new name for mickwitziid stem group brachiopods from the lower Cambrian of Greenland and Labrador: GFF, v. 132, p. 117-122, https://doi. org/10.1080/11035897.2010.490878.

Skovsted, C.B., Knight, I., Balthasar, K.U., and Boyce, W.D., 2017, Depth related brachiopod faunas from the lower Cambrian Forteau Formation of southern Labrador and western Newfoundland, Canada: Palaeontologia Electronica, v. 20, 54A, https://doi.org/10.26879/775.

Skovsted, C.B., Balthasar, U., Vinther, J., and Sperling, E.A., 2021, Small shelly fossils and carbon isotopes from the early Cambrian (Stages 3-4) Mural Formation of western Laurentia: Papers in Palaeontology, v. 7, p. 951-983, https://doi.org/10.1002/spp2.1313.

Stewart, J.H., 1970, Upper Precambrian and lower Cambrian strata in the southern Great Basin, California and Nevada: U.S. Geological Survey Professional Paper, v. 620, p. 1-206.

Stewart, J.H., and Poole, F.G., 1975, Extension of the Cordilleran Miogeosynclinal Belt to the San Andreas Fault, South California: Geological Society of America Bulletin, v. 86, p. 205-212.

Sun, W.G., and Hou, X.G., 1987, [Early Cambrian medusae from Chengjiang, Yunnan, China]: Acta Palaeontologica Sinica, v. 26, p. 257-270. [in Chinese with English abstract]

Sundberg, F.A., and McCollum, L.B., 2003, Early and mid Cambrian trilobites from the outer-shelf deposits of Nevada and California, USA: Palaeontology, v. 46, p. 945-986, https://doi.org/10.1111/1475-4983.00328.

Termier, G., and Termier, H., 1974, Les brachiopodes Cambriens de la Montagne Noire (sud de la France): Géologie Méditerranéenne, v. 1, p. 35-52.

Topper, T.P., Strotz, L.C., Holmer, L.E., Zhang, Z.-F., Tait, N.N., and Caron, J.B., 2015, Competition and mimicry: The curious case of chaetae in brachiopods from the middle Cambrian Burgess Shale: BMC Evolutionary Biology, v. 15, p. 42, https://doi.org/10.1186/s12862-015-0314-4.

Ushatinskaya, G.T., 1987, [Unusual inarticulate brachiopods from the lower Cambrian of Mongolia]: Paleontologicheskiy Zhurnal, v. 2, p. 62-68. [in Russian]

Ushatinskaya, G.T., 2008, Origin and dispersal of the earliest brachiopods: Paleontological Journal, v. 42, p. 776-791, https://doi.org/10.1134/ S0031030108080029.

Vaccari, N.E., 1988, Primer hallazgo de trilobites del Cámbrico inferior en la Provincia de La Rioja (Precordillera Septentrional): Revista de la Asociación Geológica Argentina, v. 43, p. 558-561.

Waggoner, B.M., and Collins, A.G., 1995, A new chondrophorine (Cnidaria, Hydrozoa) from the Cadiz Formation (middle Cambrian) of California: Paläontologische Zeitschrift, v. 69, p. 7-17.

Waggoner, B., and Hagadorn, J.W., 2004, An unmineralized alga from the lower Cambrian of California, USA: Neues Jahrbuch für Geologie und Paläontologie, Abhandlungen, v. 231, p. 67-83, https://doi.org/10.1127/ njgpa/231/2004/67.

Waggoner, B., and Hagadorn, J.W., 2005, Conical fossils from the lower Cambrian of eastern California: PaleoBios, v. 25, p. 1-10.

Walcott, C.D., 1884, Paleontology of the Eureka district, Nevada: U.S. Geological Survey Monograph 8, $298 \mathrm{p}$.

Walcott, C.D., 1886, Second contribution to studies on the Cambrian faunas of North America: U.S. Geological Survey Bulletin, v. 30, 369 p.

Walcott, C.D., 1887, Fauna of the \&lsquo;upper Taconic\&rsquo; of Emmons in Washington County, New York: American Journal of Science, ser. 3, v. 34 p. 187-199.

Walcott, C.D., 1897, Cambrian Brachiopoda: Genera Iphidia and Yorkia, with descriptions of new species of each and of the genus Acrothele: Proceedings of the United States National Museum, v. 19, p. 707-718.
Walcott, C.D., 1902, Cambrian Brachiopoda: Acrotreta; Linnarssonella; Obolus; with descriptions of new species: Proceedings of the United States National Museum, v. 25, p. 577-612.

Walcott, C.D., 1905, Cambrian Brachiopoda with descriptions of new genera and species: Proceedings of the United States National Museum, v. 18, p. 227-337.

Walcott, C.D., 1908, Cambrian geology and paleontology, no. 3, Cambrian Brachiopoda: Description of new genera and species: Smithsonian Miscellaneous Collections, v. 53, p. 53-137.

Walcott, C.D., 1910, Cambrian geology and paleontology, number 6, Olenellus and other genera of the Mesonacidae: Smithsonian Miscellaneous Collections, v. 53 , p. $231-422$

Walcott, C.D., 1912, Cambrian Brachiopoda: U.S. Geological Survey Monographs, v. 51, $700 \mathrm{p}$.

Walcott, C.D., 1913, New lower Cambrian subfauna: Smithsonian Miscellaneous Collections, v. 57, p. 309-326.

Walcott, C.D., 1924, Cambrian geology and palaeontology, number 4, Cambrian and Ozarkian Brachiopoda: Smithsonian Miscellaneous Collections, v. 67, p. $477-554$.

Walcott, C.D., 1931, Addenda to descriptions of Burgess Shale fossils: Smithsonian Miscellaneous Collections, v. 85, p. 1-46.

White, C.A., 1874, Preliminary report upon invertebrate fossils collected by the expeditions of 1871, 1872 and 1873 with descriptions from species: Geographical Surveys West of the 100th Meridian (U.S.), p. 5-27.

Whiteaves, J.F., 1892, Description of a new genus and species of phyllocarid Crustacea from the middle Cambrian of Mount Stephen, B.C.: Canadian Record of Science, v. 5, p. 205-208.

Williams, A., Carlson, S.J., Brunton, C.H.C., Holmer, L.E., and Popov, L.E., 1996, A supra-ordinal classification of the Brachiopoda: Philosophical Transactions of the Royal Society of London, ser. B, v. 351, p. 1171-1193.

Williams, A., Popov, L.E., Holmer, L.E., and Cusack, M., 1998, The diversity and phylogeny of paterinate brachiopods: Palaeontology, v. 41, p. 221-262.

Woodward, S.P., 1851-1856, A Manual of the Mollusca: London, John Weale, $488 \mathrm{p}$.

Wright, A.D., 1981, The external surface of Dictyonella and of other pitted brachiopods: Palaeontology, v. 24, p. 443-482.

Zhan, R.B., and Harper, D.A.T., 2006, Biotic diachroneity during the Ordovician radiation: Evidence from South China: Lethaia, v. 39, p. 211-226, https://doi.org/10.1080/00241160600799770.

Zhang, X.L., Ahlberg, P., Babcock, L.E., Choi, D.K., Geyer, G., Gozalo, R., Hollingsworth, J.S., Li, G.X., Naimark, E.B., Tatyana, P., Steiner M., Wotte, T., and Zhang, Z.-F., 2017, Challenges in defining the base of Cambrian Series 2 and Stage 3: Earth-Science Reviews, v. 172, p. 124-139, https://doi.org/10.1016/j.earscirev.2017.07.017.

Zhang, Z.-F., Strotz, L.C., Topper, T.P., Chen, F.Y., Chen, Y.L., Liang, Y., Zhang, Z.L., Skovsted, C.B., and Brock, G.A., 2020a, An encrusting kleptoparasite-host interaction from the early Cambrian: Nature Communications, v. 11, p. 2625, https://doi.org/10.1038/s41467-020-16332-3.

Zhang, Z.-F., Holmer, L.E., Liang, Y., Chen, Y.L., and Duan, X.-L., 2020b, The oldest \&lsquo; Lingulellotreta\&lsquo; (Lingulata, Brachiopoda) from China and its phylogenetic significance: Integrating new material from the Cambrian Stage 3-4 Lagerstätten in eastern Yunnan, South China: Journal of Systematic Palaeontology, v. 18, p. 945-973, https://doi.org/10.1080/ 14772019.2019.1698669.

Zhao, F.C., Zhu, M.Y., and Hu, S.X., 2010, Community structure and composition of the Cambrian Chengjiang biota: Science China Earth Sciences, v. 53 , p. 1784-1799.

Accepted: 25 July 2021 